\title{
Assessment of the Local Perceptions on the Drivers of Deforestation and Forest Degradation, Agents of Drivers, and Appropriate Activities in Cambodia
}

\author{
Sereyrotha Ken ${ }^{1,2, *}$, Nophea Sasaki ${ }^{3, *}$ C , Tomoe Entani ${ }^{1}$, Hwan Ok Ma ${ }^{4}$, Phalla Thuch ${ }^{5}$ \\ and Takuji W. Tsusaka ${ }^{3}$ (I) \\ 1 Graduate School of Applied Informatics, University of Hyogo, Hyogo 651-2197, Japan; \\ entani@ai.u-hyogo.ac.jp \\ 2 Wildlife Conservation Society, Phnom Penh 12000, Cambodia \\ 3 Natural Resources Management of Asian Institute of Technology, Pathumthani 12120, Thailand; \\ takuji@ait.ac.th \\ 4 International Tropical Timber Organization, Yokohama 220-0012, Japan; ma@itto.int \\ 5 Forestry Administration, Phnom Penh 12205, Cambodia; thuch.phalla2018@gmail.com \\ * Correspondence: ab181201@ai.u-hyogo.ac.jp or ken.rotha@gmail.com (S.K.); nopheas@ait.ac.th (N.S.)
}

Received: 2 October 2020; Accepted: 26 November 2020; Published: 29 November 2020

\begin{abstract}
Understanding the drivers of deforestation and forest degradation and the agents of such drivers is important for introducing appropriate policy interventions. Here, we identified drivers and agents of drivers through the analysis of local perceptions using questionnaire surveys, focus group discussions, and field observations. The Likert scale technique was employed for designing the questionnaire with scores ranging from 1 (strongly disagree) to 5 (strongly agree). We found nine direct drivers of forest deforestation and forest degradation, namely illegal logging $(4.53 \pm 0.60, \pm$ is for standard deviation), commercial wood production $(4.20 \pm 0.71)$, land clearing for commercial agriculture $(4.19 \pm 1.15)$, charcoal production $(3.60 \pm 1.12)$, land clearing for subsistence agriculture (3.54 \pm 0.75$)$, new settlement and land migration $(3.43 \pm 0.81)$, natural disasters $(3.31 \pm 0.96)$, human-induced forest fires $(3.25 \pm 0.96)$, and fuelwood for domestic consumption (3.21 \pm 0.77$)$. We also found four main indirect drivers, namely lack of law enforcement, demand for timber, land tenure right, and population growth. Our analysis indicates that wood furniture makers, medium and large-scale agricultural investors, charcoal makers, land migrants, firewood collectors, and subsistent farmers were the agents of these drivers. Through focus group discussions, 12 activities were agreed upon and could be introduced to reduce these drivers. In addition to enforcing the laws, creating income-generating opportunities for locals along with the provision of environmental education could ensure long-term reduction of these drivers. The REDD+ project could be an option for creating local income opportunities, while reducing deforestation and forest degradation.
\end{abstract}

Keywords: illegal logging; law enforcement; REDD+; Likert scale; binary probit; Cambodia

\section{Introduction}

Forests play important roles in subsistent livelihoods of billions of people around the world [1], providing wood fuel as energy for daily cooking and warmth [2-4], hosting various types wildlife habitats $[5,6]$, protecting biodiversity $[7,8]$, and maintaining the full functions of the ecosystem services [9]. Unfortunately, overexploitation and clearing of forest resources to meet the basic needs of an increasing population and for supporting economic growth have caused rapid loss of forests, especially in the tropics, where more than two-thirds of the world's biodiversity is found [7]. Such loss due to forest clearing and forest degradation cause significant loss of biodiversity [10] in addition 
to releasing between $10 \%$ and $25 \%$ of global carbon emissions [11]. In fact, the world lost about 26 million hectares (ha) of forests annually between 2014 and 2018, with about $90 \%$ of it occurring in the tropics [12]. To avoid further loss and the consequences on human beings and the economy, it is critically urgently important that we take immediate actions to reduce or even reverse the trend of forest cover loss at any scale.

Loss of tropical forests (deforestation and forest degradation or D \& D hereafter) is caused by various drivers, which occur at different scales [13-15]. Since drivers of D \& D occur across scales, national, and international boundaries, reducing or eliminating any of these drivers requires national and international cooperation. Foreseeing the urgent need for international cooperation to reduce these drivers as well as forest cover loss, a broad coalition of governments, companies, civil society, and indigenous peoples' organizations endorsed the New York Declaration on Forest in 2014 with 10 important goals to halt the tropical deforestation by 2020 and to restore 350 million ha of the degraded forestlands by 2030 [12]. Another important international agreement is the REDD+ scheme (reducing emissions from deforestation and forest degradation, conversation, sustainable management of forests, and enhancement of forest carbon stocks) of the United Nations Framework Convention on Climate (UNFCCC), which was introduced in 2007 [16] and ever since has been known as the result-based payment for developing countries for their activities implemented to reduce D \& D and related carbon emissions [17]. Apart from these landmark agreements, the UN's Sustainable Development Goal 15 was also agreed by the world leaders to manage and restore the tropical forests by 2030. However, despite such agreements and countless efforts, the rate of deforestation and forest degradation has not been slowing down [12]. Due to the complexity of the deforestation and forest degradation processes [18,19], previous studies suggest the need to understand the drivers and agents of these drivers before introducing any activities or interventions that are effective in reducing them [18]. Accordingly, when these drivers are reduced or eliminated, D \& D and their associated carbon emissions can also be reduced. Understanding these drivers is equally important for designing and implementing REDD+ activities that involve multi-stakeholder participation [20,21].

Identification of the drivers of D \& D is important for all member countries of the United Nations Framework Convention on Climate Change (UNFCCC) because they need to develop national REDD+ strategies; in which drivers, agents of drivers, intervention policies, and activities need to be included as part of the requirements for the REDD+ result-based payment scheme. Scientists have attempted to document the drivers of D \& D across the tropics. Hosonuma et al. [22] analyzed the drivers in self-reported REDD+ readiness activities and the Readiness Plan Idea Notes (R-PIN) prepared for the Forest Carbon Partnership Facility of the World Bank in 46 countries. They identified five types of drivers of deforestation and four types of drivers of forest degradation (Table S1). In Cambodia, drivers of $\mathrm{D} \& \mathrm{D}$ are difficult to identify due to complicated demands and links between locals and different stakeholders [23] (Table S2).

Until recently, various methods have been used to identify the drivers of deforestation and forest degradation. On a global scale, Curtis et al. [18] used satellite imagery and a forest loss classification model to identify the drivers of D \& D. They found that clearing of forests for commodity production was the main driver $(27 \%)$, followed by logging activities (i.e., forestry, $26 \%)$, shifting agriculture $(24 \%)$, and wildfire (23\%). Using a questionnaire survey to collect information from landscape managers who manage 28 tropical landscapes around the tropics, Jayathilake et al. [19] identified some of the major drivers of $\mathrm{D} \& \mathrm{D}$ in the surveyed regions. Their findings indicate that commercial and subsistence agriculture were the main drivers of deforestation, followed by settlement expansion and infrastructure development. Specifically, land was cleared for rice, rubber, cassava, and maize cultivation in these emblematic conservation landscapes. By conducting and analyzing data available in scientific literature and national and international reports, Green et al. [20] identified the five main drivers of deforestation on all tropical continents: urban expansion, infrastructure, mining, agriculture for local subsistence, and agriculture for commercial purposes. They further identified the four main drivers of forest degradation: livestock grazing in forests, uncontrolled fires, fuelwood charcoal, and timber logging. 
Although previous studies on identification of the drivers provide useful insights into the causes of tropical deforestation, they failed to focus on drivers that were actually perceived to be essential for the survival of the local people, especially for those whose livelihoods have depended on forest ecosystem services for subsistence over many generations. In Vietnam, Van Khuc et al. [15] suggested the need to understand the drivers at the local level before introducing any interventions to reduce D \& D. As the drivers involve many agents, any policy interventions are doomed to failure if they do not address the individual agents of the drivers [24]. Skutsch and Turnhout [24] analyzed the drivers of D \& D in 12 countries across the tropics and found that local agents were responsible for more than $70 \%$ of D \& D drivers. This showed that it is important to identify the drivers and their agents at the local level through direct interviews and field observations before proposing any policy interventions for effective implementation. This study aims to identify the drivers of deforestation and forest degradation, agents of these drivers, and the appropriate activities for reducing these drivers, through analysis of local perceptions in Kampong Thom province, Cambodia. Field questionnaire surveys, focus group discussions, and field observations were conducted in seven communities adjacent to the recently validated Tumring REDD+ project site located in the Prey Long Wildlife Sanctuary in Kompong Thom province, Cambodia. Local perceptions were analyzed using the Likert scale scoring method.

\section{Study Methods and Materials}

\subsection{Overview of Drivers of Deforestation and Forest Degradation}

In its report to the Forest Carbon Partnership Facility (FPCF) in 2011 [23], Cambodia classified drivers of $\mathrm{D} \& \mathrm{D}$ as direct and indirect drivers within and outside forest sector. There were 6 direct drivers and 24 indirect drivers (Table 1).

Table 1. Drivers of deforestation and forest degradation within and outside the forest sector in Cambodia.

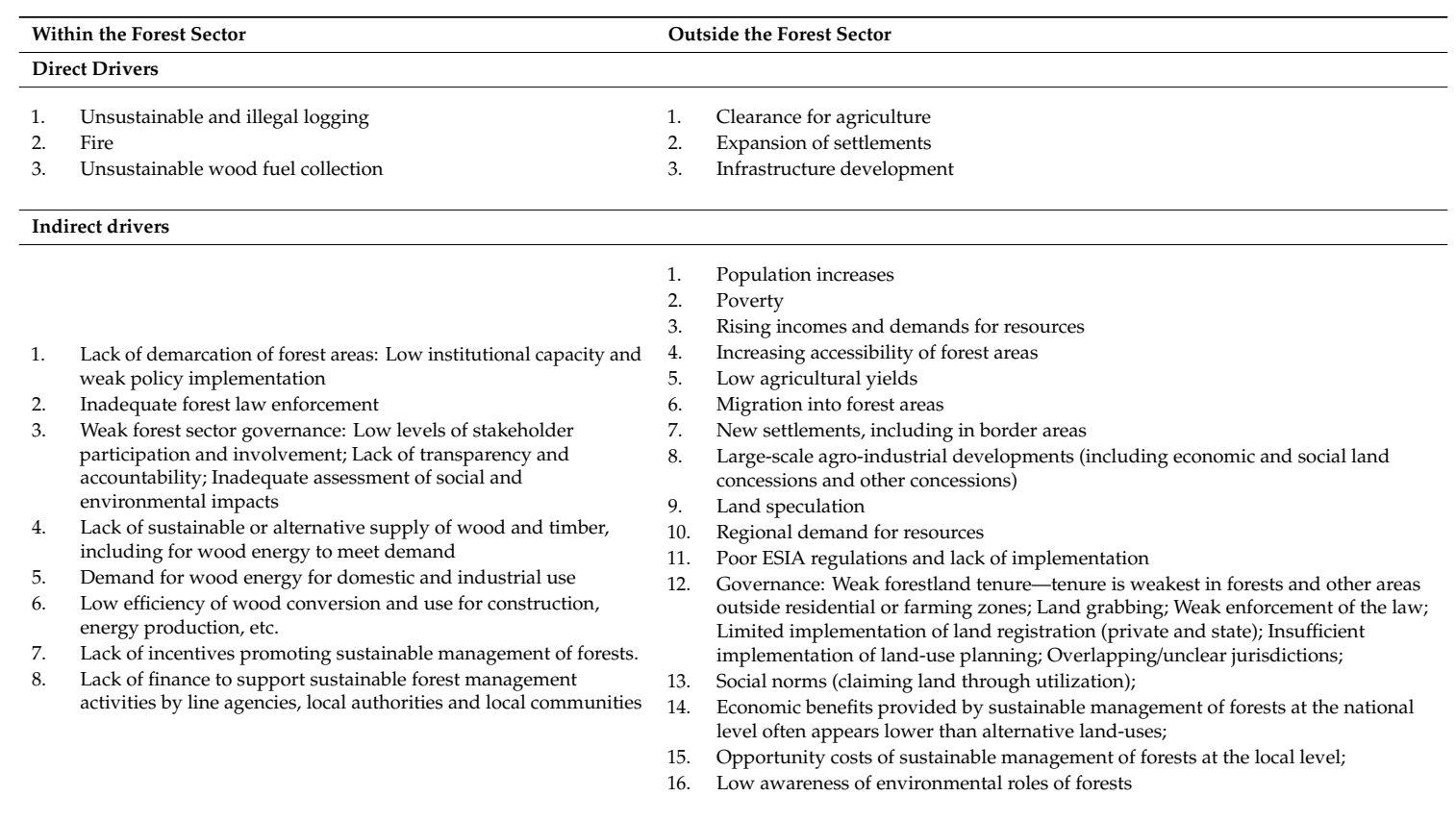

Source: Adapted from FCPC \& UN-REDD [23].

Drivers in Table 1 were used in the focus group discussions to discuss whether to accept, eliminate or add additional drivers prior to conducting the individual household surveys. 


\subsection{Description of the Study Area}

The study area was located in Kampong Thom province, Cambodia. It was part of a Forestry Administration's feasibility study project, sponsored by the International Tropical Timber Organization (ITTO) in 2015, under the project name "Sustainable Forest Management through REDD+ mechanisms in Kampong Thom province, Cambodia." This project covered a total of 23 forestry communities with a total population of 5267 families. The fieldwork of this study was conducted in seven of the 23 forestry communities. These communities include Veal O Khdey, Prey Cheam Smach, Prey Naktala, Prey Kbal Daun Tey, Prey Kbal Ou Kror Nhak, Beong Rolom, and Andoung Pring, located inside the Prey Long Wildlife Sanctuary in Kompong Thom province, Cambodia (Figure 1).

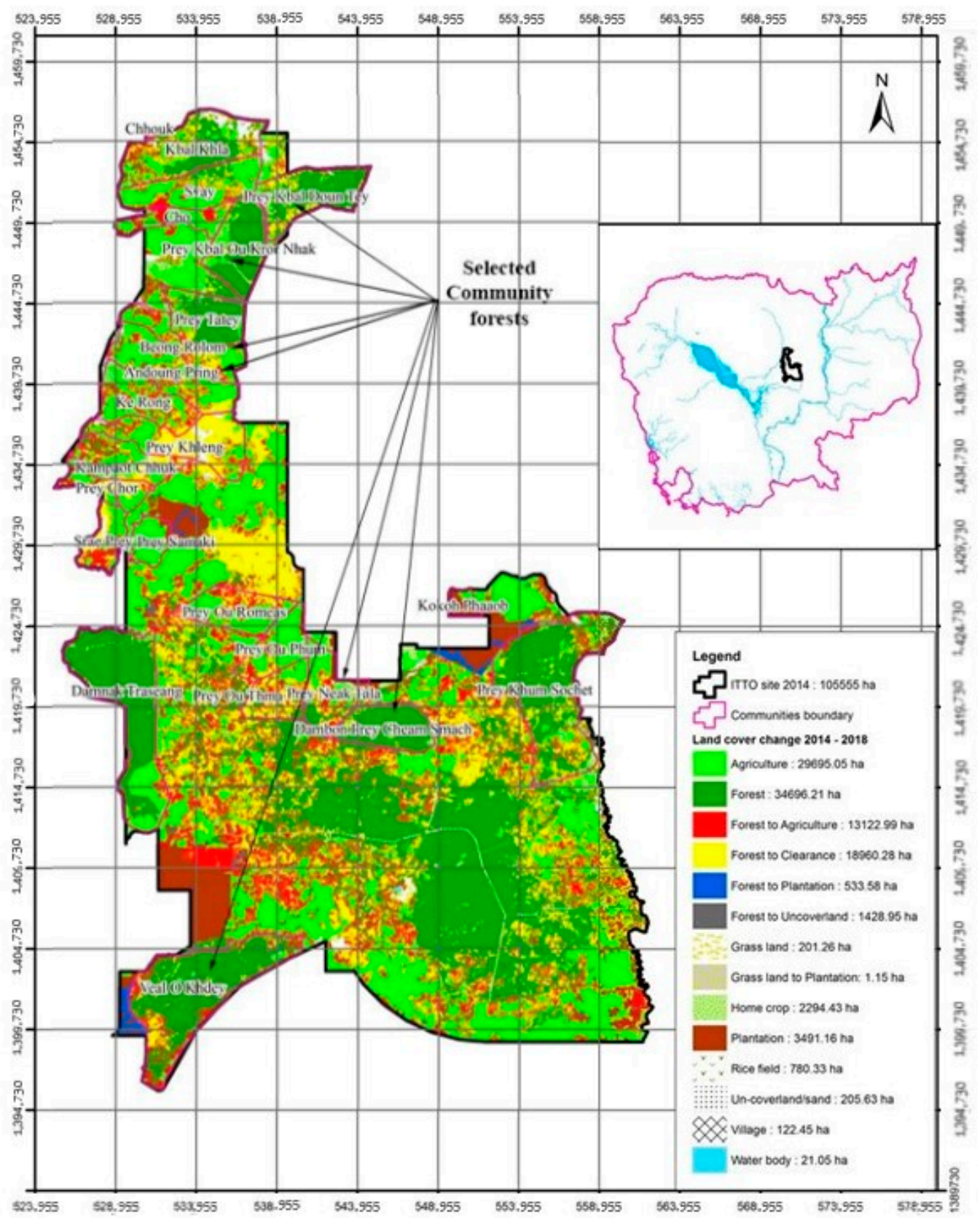

Figure 1. Map of study area and selected community forests for the survey. Source: This map was produced by the authors. 


\subsection{Data Collection}

Both the questionnaire survey and the focus group discussions were conducted to understand the drivers and agents of $\mathrm{D} \& \mathrm{D}$, and to obtain a consensus among the local communities on appropriate activities for addressing the drivers and their agents. The questionnaire was designed according to the Likert scale format to elicit the degree of agreement from local residents about what the drivers and agents of D \& D in their area are, as well as suitable solutions for their region. On the Likert scale, scores 1, 2, 3, 4, and 5 refer to strongly disagree, disagree, neutral, agree, and strongly agree, respectively, regarding the associated questionnaire statement. The drivers and agents of D \& D with scores from 3 to 5 were considered as the perceived drivers and agents of forest loss in the study areas. Additionally, the measures taken (e.g., agricultural intensification, law enforcement on illegal logging, and community forest management) to address the drivers of D \& D applicable to the study area were derived based on the interpretation of focus group discussions and the survey results. A few activities (e.g., environmental, and social impact assessment for development proposal, building infrastructure, and agroforestry) that received a score below 3 were excluded from the study due to feasibility constraints and unsuitability to the area. The perception of nine direct drivers and 11 indirect drivers was elicited. For this study, direct drivers included illegal logging/unauthorized forest encroachment, commercial wood production, land clearing for commercial agriculture, charcoal production, land clearance for subsistence agriculture, new settlements/migration, natural disasters (floods, storms), human-induced forest fires, and fuelwood (domestic usage or local consumption). Indirect drivers included road construction, population growth, public service, mining, hydropower development, shifting cultivation, livestock grazing, application of the wood sector, fertile land availability limitation, land tenure and rights issues, and limitations in law enforcement on illegal logging. Additionally, focus group discussions were used to support and interpret the responses to the survey and to corroborate the reliability of the survey results and their implications.

\subsection{Sampling}

\subsubsection{Household Surveys}

The surveys were conducted in August 2018 covering seven community forests in Kampong Thom, Cambodia (Figure 1). These communities were purposively selected as they were located in or near the areas where the highest rate of forest cover change was observed (Figure 1).

The minimum suggested sample size was calculated using the following formula proposed by Yamane [25]:

$$
n=\frac{N}{1+N e^{2}}
$$

where:

$n=$ minimum suggested sample size

$N=$ household population in the ITTO project area (5267 households)

$e=$ margin of error (5 to $10 \%)$

According to Equation (1), the minimum suggested sample size was in the range of 98 to 372 , based on which we aimed to interview approximately 200 households. In case any errors in data collection led to usable observations, we aimed to interview $10 \%$ additional households, resulting in 219 households in total in the study area. Four of them were intentionally removed because some information was missing from their data. In each community, the households were randomly selected from the roster obtained from the community leader. Table 2 shows the number and percentage of households surveyed in each community forest. Due to difficulties in local moving from one house to another in the rural areas, convenient sampling was adopted. We randomly visited the house and interviewed whether the farmer was present. In the case where a wife and husband were at home, only the husband was asked because the husband is the common head of the household in Cambodia. 
Table 2. Number and percentage of households interviewed in the selected community forests.

\begin{tabular}{lcc}
\hline \multicolumn{1}{c}{ Community Forest } & Sample Size & Percentage (\%) \\
\hline 1. Veal O Khdey & 31 & 14.4 \\
2. Prey Cheam Smach & 31 & 14.4 \\
3. Prey Naktala & 32 & 14.9 \\
4. Prey Kbal Daun Tey & 30 & 14.0 \\
5. Prey Kbal Ou Kror Nhak & 32 & 14.9 \\
6. Beong Rolom & 28 & 13.0 \\
7. Andoung Pring & 31 & 14.4 \\
\hline Total $(n)$ after removing the invalid entries & 215 & 100 \\
\hline
\end{tabular}

\subsubsection{Focus Group Discussions}

In almost every country, previous studies have shown the need to integrate local communities and their acceptance of conservation planning and practices for long-term success [26-28]. We organized focus group discussions with senior locals who have lived in the study area long enough to understand the changes that have occurred, to agree on and/or eliminate the general drivers of D \& D that were found elsewhere in Cambodia so as to save time for asking questions that were not actually seen in the study area, and to understand locals' acceptance of driver agents and appropriate activities for reducing the drivers. These focus group discussions also served to re-affirm the results from the individual surveys in the study area. The main criteria for selecting the focus group participants was that they were locals who had lived in the study area for at least 10 years in order to ensure that the they were knowledgeable about forest clearing, logging, and other land clearing activities by locals, private companies, and others. With these criteria, and in consultation with government officials and village chiefs, 72 participants (39 of which were female) were chosen. Their residences were unevenly distributed throughout the study areas (Table 3). Accordingly, four focus groups held discussions separately, in Prey Cheam Smach (18 participants), Prey Naktala (18), Prey Kbal Ou Kror Nhak (19), and Prey Kbal Daun Tey (17) villages on the 28th and 29th of August 2018. Initially, the perceived agents of D \& D were obtained through household surveys. These perceived agents were comprehensively described and explained to the participants during the focus group discussions. Members were then asked to reach a consensus on the actual existence of the agents of D \& D in the study area.

Table 3. Number of participants in the focus group discussion for each community forest.

\begin{tabular}{ccc}
\hline Community Forest & Number of Participants & Number of Female Participants \\
\hline Prey Cheam Smach & 18 & 12 \\
Prey Naktala & 18 & 6 \\
Prey Kbal Ou Kror Nhak & 19 & 13 \\
Prey Kbal Daun Tey & 17 & 8 \\
\hline Total & 72 & 39 \\
\hline
\end{tabular}

\subsection{Analysis}

The descriptive statistics for the five-level ordinal variables representing the extent of agreement with nine direct drivers, 11 indirect drivers, 11 types of agents, and 18 types of REDD+ activities were analyzed using frequency distribution, mean, median, and standard deviation. For articulation, these drivers, agents, and activities were ranked per respective category according to their mean scores. The quantitative results are discussed in conjunction with insights from the focus group discussions. In addition, regression analysis was employed to examine how sociodemographic factors influenced the perceived drivers, agents, and activities for reducing the drivers. We initially estimated the ordered probit model. However, in our attempts to test for the parallel-lines assumption, the iterations in the 
maximum likelihood estimation failed to converge because of the concentration of observations in less than three values. In fact, most of the ordinal variables representing the perception were found to have their observations concentrated in one or two levels. Hence, the ordinal variables were converted to binary scale for analysis in a probit regression [29] rather than applying ordinal regression models [30]. After removing multicollinear variables based on the VIF (variance inflation factor), 11 independent variables were included in this analysis: woman dummy ( 1 if a woman), age, marriage dummy (1 if married), household size (headcount), secondary school dummy (1 if completed), residency duration (years), farmer dummy (1 if a farmer), occupation duration (years), income (natural logarithm of annual income in US dollar), CF membership dummy (1 if a member), and CF management dummy (1 if participating in management). Lastly, the heteroscedasticity robust standard errors were used to account for unknown structures of variation. The quantitative analyses were performed using STATA 16.

\section{Results and Discussions}

\subsection{Respondent's Profiles}

Although the sampling unit was households, key variables were based on respondents' individual perceptions. Therefore, most of the information collected on basic profiles were the respondents' sociodemographic variables rather than household characteristics, with the exception of family size and household income. Accordingly, Table 4 summarizes the descriptive statistics of the respondents' profiles. More than two-thirds (68\%) of the respondents were women, and the rest (32\%) were men. The higher number of female respondents was due to their availability during the time of the survey. Most women were at home, while men were in the field or far from home. Many of the men were labor workers in Thailand or South Korea. The respondents' ages ranged from 18 to 81 years. The combined age segment from 18 to 50 accounted for $69.7 \%$ of the sample. Some of these adults worked on farms or used to go to the forest to collect NTFPs, and participated in forest protection and management, in roles such as rangers. Therefore, they witnessed how the forest in their community had previously degraded or deforested. Furthermore, $30.3 \%$ of the sample was above 50 years old. These people had experience and knowledge about the changes in forest cover and other conditions in their community and were thus able to provide perspectives on how and why local forested regions were lost or degraded.

The majority ( $88.8 \%$ ) of the respondents were married, while only $0.5 \%$ were single, $2.8 \%$ divorced, and the remaining 7.9\% were of an unknown relationship status (Table 4). Most (70.2\%) of the households had 4 to 7 family members. Smaller households accounted for $21.9 \%$, and larger households accounted for $7.9 \%$. Many (38.1\%) of the respondents were educated up to primary school, $26.5 \%$ were illiterate, $21.4 \%$ finished secondary school, and only $7.0 \%$ completed high school. Most $(70.2 \%)$ of the respondents had been living in the studied area for more than 20 years, $15.4 \%$ had up to 10 years of residency, and $14.4 \%$ had $11-20$ years of residency. Most (80.5\%) of the respondents were farmers, followed by labor workers $(8.4 \%)$, business persons $(5.1 \%)$, NTFPs collectors, and government officers $(0.9 \%$ each). About half $(54.9 \%)$ of them had been in the same occupation for 10 years or less. The average household income was estimated to be approximately two thousand US dollars per annum.

To our surprise, it was revealed that two-thirds $(68.8 \%)$ of the respondents were members of the forest communities. However, only $43.7 \%$ had ever participated in activities related to forest management or conservation, such as attending forestry-related meetings or being forest rangers. 
Table 4. Profile of the survey respondents in the study area $(n=215)$.

\begin{tabular}{|c|c|c|c|}
\hline Sociodemographic Profile Variable & Category or Level & Frequency (\%) & $\begin{array}{l}\text { Mean } \\
\text { (SD) }\end{array}$ \\
\hline \multirow{2}{*}{ Gender of respondent * } & Male & 32.6 & \\
\hline & Female & 67.4 & \\
\hline \multirow{5}{*}{ Age of respondent (years) } & $18-30$ & 23.7 & \multirow{5}{*}{$\begin{array}{c}42.3 \\
(14.3)\end{array}$} \\
\hline & $31-40$ & 28.8 & \\
\hline & $41-50$ & 17.2 & \\
\hline & $51-60$ & 17.7 & \\
\hline & $>60$ & 12.6 & \\
\hline \multirow{4}{*}{ Marital status of respondent } & Single & 0.5 & \multirow{4}{*}{ NA } \\
\hline & Married & 88.8 & \\
\hline & Divorced & 2.8 & \\
\hline & Other & 7.9 & \\
\hline \multirow{3}{*}{ Household size (headcount) } & Less than 4 & 21.9 & \multirow{3}{*}{$\begin{array}{c}4.8 \\
(1.6)\end{array}$} \\
\hline & $4-7$ & 70.2 & \\
\hline & More than 7 & 7.9 & \\
\hline \multirow{8}{*}{ Level of education of respondent } & No education & 26.5 & \multirow{8}{*}{ NA } \\
\hline & Informal education at pagoda & 1.9 & \\
\hline & Literacy class & 2.8 & \\
\hline & Primary school & 38.1 & \\
\hline & Secondary school & 21.4 & \\
\hline & High school & 7.0 & \\
\hline & Diploma, vocational Education & 0.5 & \\
\hline & College or higher & 1.9 & \\
\hline \multirow{4}{*}{ Duration of residency of respondent (years) } & $1-10$ & 15.4 & \multirow{4}{*}{$\begin{array}{c}32.9 \\
(18.4)\end{array}$} \\
\hline & $11-20$ & 14.4 & \\
\hline & $21-30$ & 16.7 & \\
\hline & $>30$ & 53.5 & \\
\hline \multirow{7}{*}{ Primary occupation of respondent } & Farmer & 80.5 & \multirow{7}{*}{ NA } \\
\hline & Labor worker & 8.4 & \\
\hline & Businessperson & 5.1 & \\
\hline & Government officer & 0.9 & \\
\hline & NTFPs collector & 0.9 & \\
\hline & Rancher & 0.5 & \\
\hline & Other & 3.7 & \\
\hline \multirow{4}{*}{ Duration with primary occupation (years) } & $1-10$ & 54.9 & \multirow{4}{*}{$\begin{array}{c}16.4 \\
(14.0)\end{array}$} \\
\hline & $11-20$ & 15.8 & \\
\hline & $21-30$ & 10.7 & \\
\hline & $>30$ & 18.6 & \\
\hline \multirow{4}{*}{$\begin{array}{l}\text { Household income from primary } \\
\text { occupation (USD/year) }\end{array}$} & $<500$ & 28.4 & \multirow{4}{*}{$\begin{array}{c}1266.3 \\
(1604.8)\end{array}$} \\
\hline & $500-1000$ & 39.1 & \\
\hline & $1001-2000$ & 15.8 & \\
\hline & $>2000$ & 16.7 & \\
\hline \multirow{4}{*}{$\begin{array}{l}\text { Household income from other occupations } \\
\text { (USD/year) }\end{array}$} & $<500$ & 61.4 & \multirow{4}{*}{$\begin{array}{c}790.7 \\
(1181.2)\end{array}$} \\
\hline & $500-1000$ & 9.3 & \\
\hline & $1001-2000$ & 21.9 & \\
\hline & $>2000$ & 7.4 & \\
\hline \multirow{2}{*}{ Community forest by respondent } & Member & 68.8 & \multirow{2}{*}{ NA } \\
\hline & Non member & 31.2 & \\
\hline \multirow{2}{*}{$\begin{array}{l}\text { Participation in forest management } \\
\text { committee by respondent }\end{array}$} & Participant & 43.7 & \\
\hline & Non participant & 56.3 & NA \\
\hline
\end{tabular}

Note: * The respondent was the adult person who was at home at the time of interviews. 


\subsection{Drivers of Deforestation and Forest Degradation in the Study Area}

\subsubsection{Direct Drivers}

Table 5 presents the descriptive statistics of the responses to the Likert-scale questionnaire on direct drivers of D \& D. Of the nine items assessed, the top three direct drivers of D \& D were illegal logging and unauthorized encroachment, commercial wood production, and land clearing for commercial agriculture. For these drivers, the average score exceeded 4.0. The other direct drivers had average scores between 3.0 and 4.0. Among them, charcoal production and land clearing for subsistence cultivation were perceived as relatively important direct drivers of D \& D.

Table 5. Extent of agreement to the nine direct drivers of deforestation and forest degradation in the study area $(n=215)$.

\begin{tabular}{llcc}
\hline & \multicolumn{1}{c}{ Direct Driver } & Mean Score (SD) & Median Score \\
\hline N1 & Illegal logging/unauthorized forest encroachment & $4.53(0.60)$ & 5 \\
N2 & Commercial wood production & $4.20(0.71)$ & 4 \\
N3 & Land clearing for commercial agriculture & $4.19(1.15)$ & 5 \\
N4 & Charcoal production & $3.60(1.12)$ & 4 \\
N5 & Land clearance for subsistence agriculture & $3.54(0.75)$ & 4 \\
N6 & New settlements/migration & $3.43(0.81)$ & 3 \\
N7 & Natural disaster (flood, storm) & $3.31(0.91)$ & 3 \\
N8 & Human induced forest fire & $3.25(0.96)$ & 3 \\
N9 & Fuelwood (domestic usage or local consumption) & $3.21(0.77)$ & 3 \\
\hline
\end{tabular}

Illegal logging and unauthorized encroachment: The mean rating score for this direct driver of D \& D was the highest (4.53). Almost all (97.7\%) of the respondents agreed that illegal logging was the main reason for forest degradation, and that unauthorized encroachment was the main reason for deforestation in their respective community forests. According to the focus group discussions, illegal logging was the main concern for forest degradation and eventual loss of forest cover in their community forests and surrounding areas, and that it would continue until all the forests were gone. The participants observed that there was almost no forest left near their community forests, and that their community forests were increasingly threatened by the unauthorized encroachment of outsiders. The community forests were encroached, and the trees were being felled by both local communities and outsiders, due to the lack of alternative resources for their daily subsistence and livelihoods. Furthermore, the participants noted that although people with a lower socio-economic background committed most of the illegal logging, there were instances where the more affluent were involved. In addition to illegal logging, trees were also cut down by local hunters to facilitate catching wild animals. Although the felling of trees for hunting purposes was not the major cause of forest degradation, this practice repeated over large areas could cause forest degradation and even deforestation [31]. Elsewhere in the tropics, illegal logging has also been reported as a major cause of deforestation and loss of carbon stocks in the tropics [32-35]. Delux [36] reported that land encroachment is a known driver of deforestation and forest degradation in the northeastern part of Cambodia.

Commercial wood products: This driver refers to organized logging activities involving the export of wood by trucks, for delivery to external parties. The score for this item was 4.20 , and about $87.7 \%$ of respondents perceived that commercial wood products were the second main driver of forest degradation and eventual loss of forest cover in their respective communities. In general, the participants perceived that commercial wood products triggered the need for wood in huge amounts; therefore, increasing volumes of wood were being logged for commercial export. They felt that as the loggers had little knowledge about tree felling, their tree-felling activities caused excessive damage to residual stands, resulting in rapid forest degradation and a reduction of forest cover. Collection of 
commercial wood products was a leading cause of rapid deforestation in the Philippines between the 1970s and the 1980s [37] and in the Baltistan Region of Pakistan [38].

Land clearing for commercial agriculture: The score for this item was 4.19 , with $80.4 \%$ of respondents perceiving it as a major driver of the loss of forest cover in their respective communities. Economic land concessions, offered to investors growing cassava, rubber, and cashew nut trees, has caused a huge reduction in forest cover because concessions were granted for land in forested areas. Vast tracks of forest were leased to private companies in the name of development. Moreover, these investors also profited from the sale of the wood logged while clearing the land in preparation for agriculture. Using high-resolution remote sensing data, a recent study also found that land clearing incentivized by economic land concessions has caused rapid deforestation in Cambodia [39].

Charcoal production: The score for this driver was 3.60, with $66.7 \%$ of respondents believing that charcoal production contributed to forest deforestation and forest degradation in their region. Charcoal kilns have been constructed in the project study area for commercial charcoal production, such as those in Ou Thmor and Ou Phoum. Charcoal production has caused forest degradation and deforestation in Mozambique [40], Brazil [41], and Angola [42].

Land clearing for subsistence cultivation: The score for this driver was 3.54 , with $55.2 \%$ of respondents of the opinion that subsistence cropping of local residents contributed to forest clearing. To grow more crops for agricultural purposes, locals had cleared any forest land they had access to. A recent study indicated that clearing the forest for subsistence agriculture could be due to declines in crop productivity; in order to support the livelihood of the increasing number family members more crop was sown to maintain sufficient output [43]. Depending on the country, not all subsistence cultivation causes deforestation or forest degradation. This finding is supported by studies in Indonesia (where slash-and-burn agriculture is practiced) [44], eastern Madagascar [45] and the Philippines [46]. However, Moonen et al. [47] found that subsistence cultivation in the Democratic Republic of the Congo did not cause deforestation. Instead, that clearing of forests by rich farmers for cash earnings was the cause of deforestation. Similarly, Ravikumar et al. [14] found that subsistence agriculture did not cause deforestation in the Peruvian Amazon, arguing that previous studies with results to the contrary had performed their analysis using only remotely sensed data.

New settlement: New settlements were established by the flow of migrants to the community and through increases in household family member numbers. The score for this driver was 3.44, with $47.5 \%$ of respondents perceiving it as a driver for deforestation and forest degradation. Links between migration and clearing of forests in Cambodia were also reported by Kong et al. [43] and Milne [48]. Clearing forests for new resettlements has also been reported in other tropical regions such as Brazil [49,50], Thailand [51], Vietnam [52], and Indonesia [53].

Natural disaster: This driver got a score of 3.31 out of 5, suggesting that it was also one of the drivers of forest degradation and deforestation in the region. About $45.2 \%$ of respondents agreed on this response and corroborated its impact on community forests. For example, drought and storm conditions in 2016 caused many trees to fall and eventually die, in Prey Kbal Ou Kror Nhak community forests. A recent study around Tonle Sap Great Lake, adjacent to this study area, confirmed that natural disasters can result in deforestation and forest degradation in Cambodia [54].

Human-induced forest fire: The score for this item was 3.24, with $45.7 \%$ of respondents agreeing that it was the driver of forest loss. Based on the score and the response from local people, human-induced forest fire was a recent concern for forest loss, although it occasionally occurs. Forest fire was induced by humans as a means for land clearing for agriculture and for wild animal hunting. In the tropics, human-induced fires are the main cause of large-scale deforestation and forest degradation in Brazil [55,56], Indonesia [57,58], and the Democratic Republic of the Congo [59].

Fuelwood for domestic consumption (local consumption): This driver received an average score of 3.21 . About $37.9 \%$ of respondents believed that fuelwood for domestic consumption could contribute to forest loss, but this was not a serious concern because most of the wood that they used were from dead trees or cassavas. Based on the focus group discussion, local people confirmed that there was no 
electricity available for them for use as cooking energy, and the lack of gas stoves and gas itself was so expensive that they could not afford to use gas. Therefore, the use of fuelwood for daily cooking was inevitable. When wood is required for daily consumption, this affects forest degradation and deforestation to various degrees. A study in Kampong Thom province found that the per capita wood fuel consumption rate was approximately $200 \mathrm{~kg}$ of wood per year [60]. Another study found a higher amount of fuelwood consumption for cooking and boiling, reaching $8 \mathrm{~kg}$ per day per family in Kampong Thom province, Cambodia [61]. Although respondents in the study area tend to consider this driver as less important, $100 \%$ of the Cambodian local population depends on the use of wood from nearby forests for daily cooking energy and other purposes such as boiling water, protecting animals from insect bites, making bricks, and more [61]. Therefore, this driver may be considered an important driver that needs to be addressed in different activities.

\subsubsection{Indirect Drivers}

Table 6 presents the descriptive statistics of the responses to the Likert-scale questionnaire on indirect drivers of D \& D. Of the 11 items assessed, the top two indirect drivers of D \& D were limitations in law enforcement for illegal logging and demand for timber. For these drivers, the average score exceeded 4.0. Two other indirect drivers registering an average between 3.0 and 4.0 and were land tenure and rights issues and population growth. Hydropower development was perceived as the least significant indirect driver of $\mathrm{D} \& \mathrm{D}$ in the studied area.

Table 6. Extent of agreement to the eleven indirect drivers of deforestation and forest degradation in the study area $(n=215)$.

\begin{tabular}{llcc}
\hline Indirect Drivers & $\begin{array}{c}\text { Mean } \\
\text { Score (SD) }\end{array}$ & $\begin{array}{c}\text { Median } \\
\text { Score }\end{array}$ \\
\hline P1 & Limitation in law enforcement & $4.33(0.54)$ & 4 \\
P2 & Demand for timber & $4.15(0.68)$ & 4 \\
P3 & Land tenure and rights issue & $3.72(0.78)$ & 4 \\
P4 & Population growth & $3.47(0.73)$ & 3 \\
P5 & Fertile land availability limitation & $2.94(0.97)$ & 3 \\
P6 & Road construction & $2.79(0.84)$ & 3 \\
P7 & Shifting cultivation & $2.73(0.94)$ & 3 \\
P8 & Public service & $2.32(0.89)$ & 2 \\
P9 & Mining & $1.95(0.83)$ & 2 \\
P10 & Livestock grazing & $1.85(0.69)$ & 2 \\
P11 & Hydropower development & $1.60(0.63)$ & 2 \\
\hline
\end{tabular}

Limitation in law enforcement: This indirect driver received an average score of 4.33. Almost all $(96.8 \%)$ of the respondents viewed weak enforcement of the law as the main indirect driver for $\mathrm{D} \& \mathrm{D}$ in their region. Based on focus group discussions, participants viewed the limited capacity of those involved in forest protection (such as government officers and forest rangers) to arrest illegal loggers as contributing to forest loss. The rangers normally went to the forests two to three times per week, and illegal logging occurred on other days of the week. In addition, the forest community areas are usually large, and rangers have been unable to patrol all of it. Examples include Prey Kbal Ou Kror Khak (1593 ha), Veal O Khdey (4450 ha), and Prey Kbal Doun Tey (1803 ha). Illegal loggers have been taking the absence of rangers as opportunities to fell trees. This perception was confirmed in recent studies in Cambodia [62] as well as in the Amazon forests [63], Indonesia [64], and different parts of Africa [65].

Demand for wood: This driver had an average score of 4.15 , and $84.5 \%$ of respondents perceived that increased demand for wood results in higher wood prices; therefore, wood is a high priority for illegal loggers. This driver contributed to forest degradation, i.e., gradual loss of highly valuable timber species. Focus group discussions corroborated that demand for wood was an indirect driver that 
significantly caused forest loss. Participants stated that the high price of wood and the huge demand for wood made the impoverished cut down trees to support their daily needs and that the wealthy cut down trees to out of greed. Participants also felt that if there were no buyers, there would be no sellers. Without buyers and sellers of wood, there would be no illegal logging for commercial purposes. The complicated relationship between the demand for wood, buyers and sellers, and timber fellers has been reported in various studies [66-68], indicating the existence of this driver at different scales.

Land tenure rights: The score for this indirect driver was 3.72. About $70.7 \%$ of respondents agreed that land tenure and right issues contributed to forest clearance. Local people tend to get more and more land for family purposes and for selling; therefore, they had to clear the accessible forest to get the land. Furthermore, some local people cleared the forest land that belonged to the community to grow temporary crops and probably claimed the land later. Similar clearing of land due to lack of land tenure has also been reported in different parts of the tropics, such as in Peru [69], Brazil [70], and in various countries in the tropics [71].

Population growth: This indirect driver achieved a score of 3.47 . About $50 \%$ of the local population believed that the increase in population in the study area was due to the rapid growth and influx of land migrants, and this driver put greater pressure on forest land use. Either the growth of migrant populations incentivized local residents to clear forest land to sell it to the newcomers, or migrants cleared the forest themselves for settlement and agriculture. In Vietnam, population growth is closely linked to the increased demand for and extraction of forest resources [15].

\subsection{Agents of Deforestation and Forest Degradation in the Study Area}

Table 7 shows the levels of agreement by survey respondents who were responsible for D \& D in the locality. Out of the 11 types of agent inquired about, six exhibited an average score of above 3.0, which were furniture makers (average score 4.16), medium- and large-scale agricultural investors (3.99), charcoal makers (3.54), immigrants (3.38), firewood collectors (3.24), and subsistence farmers (3.14). These six types of agent had an average score above 3.0. Ranchers were perceived as the least significant agent (1.87).

Table 7. Extent of agreement to the eleven types of agents of deforestation and forest degradation in the study area $(n=215)$.

\begin{tabular}{|c|c|c|c|c|c|c|c|c|}
\hline \multirow[t]{2}{*}{ Rank } & \multirow[t]{2}{*}{ Agents } & \multicolumn{5}{|c|}{$\begin{array}{c}\text { Frequency of Response (\% of } \\
\text { Households) in Relation to Strongly } \\
\text { Disagree (1), Disagree (2), Neutral (3), } \\
\text { Agree (4), Strongly Agree (5) }\end{array}$} & \multirow[t]{2}{*}{$\begin{array}{c}\text { Average } \\
\text { Score (SD) }\end{array}$} & \multirow[t]{2}{*}{$\begin{array}{c}\text { Median } \\
\text { Score }\end{array}$} \\
\hline & & (1) & (2) & (3) & (4) & (5) & & \\
\hline 1 & Furniture makers & 0.0 & 1.9 & 10.7 & 57.2 & 30.2 & $4.16(0.68)$ & 4 \\
\hline 2 & Medium and large-scale agricultural investors & 0.0 & 19.1 & 4.7 & 34.9 & 41.4 & $3.99(1.11)$ & 4 \\
\hline 3 & Charcoal makers & 1.4 & 27.0 & 7.4 & 44.2 & 20.0 & $3.54(1.13)$ & 4 \\
\hline 4 & Migrants & 0.5 & 10.7 & 42.8 & 42.3 & 3.7 & $3.38(0.74)$ & 3 \\
\hline 5 & Firewood collectors & 0.5 & 20.0 & 39.1 & 35.8 & 4.7 & $3.24(0.84)$ & 3 \\
\hline 6 & Subsistence farmers & 4.7 & 17.2 & 38.1 & 39.5 & 0.5 & $3.14(0.87)$ & 3 \\
\hline 7 & Shifting cultivators & 11.6 & 23.3 & 46.1 & 17.7 & 1.4 & $2.74(0.93)$ & 3 \\
\hline 8 & Infrastructural developers & 8.8 & 38.6 & 30.7 & 21.9 & 0.0 & $2.66(0.92)$ & 3 \\
\hline 9 & Mining investors & 23.3 & 43.3 & 7.9 & 21.4 & 4.2 & $2.40(1.18)$ & 2 \\
\hline 10 & Hydropower establishers & 27.9 & 42.8 & 7.4 & 19.1 & 2.8 & $2.26(1.14)$ & 2 \\
\hline 11 & Ranchers & 30.7 & 54.4 & 12.1 & 2.8 & 0.0 & $1.87(0.72)$ & 2 \\
\hline
\end{tabular}

Our focus group discussions revealed that not all the agents in Table 8 are perceived to have caused D \& D. Table 8 presents the activities undertaken by the agents that were perceived to cause D \& D in the study areas. These activities were received through the Focus Group Discussion. 
Table 8. Agents' activities that were perceived to have contributed to deforestation and forest degradation in the study area.

\begin{tabular}{ll}
\hline \multicolumn{1}{c}{ Agents } & \multicolumn{1}{c}{ Activities } \\
\hline Furniture makers & - Fell trees in huge amount for commercial wood products \\
Medium- and large-scale agricultural investors & - Trigger illegal logging from local people \\
Charcoal makers & - Convert forest land to agricultural land \\
& - Produce charcoal \\
Land migrants & - Clear forest for land settlement \\
& - Clear forest for agricultural land \\
Firewood collectors & - Trigger local people to clear forest land and sell to them \\
Subsistent farmers & - Collect wood for domestic use \\
\hline
\end{tabular}

As the real estate business booms in Cambodia, furniture is produced to supply individuals and housing complexes such as townhouses, condominiums, and villas. Furniture producers actively looked for sources of wood supply to meet the demands for their products. Wood is also sought from furniture producers in Vietnam, where furniture manufacturers also export wooden furniture to Europe [72]. Apart from wood, increasing populations and high demand for agricultural products for local consumption and export, coupled with high prices of agricultural commodities [73], have prompted medium- and large-scale agricultural investors to venture into the agricultural sector; especially after Cambodia introduced the economic land concession system in 2006 [74]. In addition, as almost 90\% of the Cambodian population still depends on fuelwood for cooking energy needs, the increasing population provides the opportunity for charcoal makers to produce more charcoal for locals to use, mainly in crowded towns in rural areas or for export to other provinces in Cambodia [19]. Apart from charcoal, local people also use firewood directly [75]. Firewood collectors collect wood and even clear forests for the collection of large amounts of firewood, for sale to consumers.

Due to the lack of land tenure rights in some parts of the study area, subsistence farmers tend to practice seasonal clearing of the forests for farming [76] with little long-term care for their farms. Similarly, migrants have been taking opportunities to clear forests for resettlement and agriculture, and even selling cleared land when the timing is right. In fact, land speculation has prompted migrants to clear the forested areas expressly for the purpose of selling land to middlemen, in anticipation of further sales at higher prices [77]. Migrants have also caused deforestation in Brazil, Bolivia, Colombia, Ecuador, Perú, and Venezuela [78], Madagascar [79], and Indonesia [80].

Through the focus group discussions, we could conclude that these five agents of D \& D (Table 9) were not perceived as responsible for $\mathrm{D} \& \mathrm{D}$ in the area. The major reasons for this are as follows.

Table 9. Agents and reasons for excluding them from project study.

\begin{tabular}{ll}
\hline \multicolumn{1}{c}{ Agents } & \multicolumn{1}{c}{ Reason } \\
\hline Shifting cultivator & No more practice in the region \\
Infrastructural developers & No effect on forests since the road was built or repaired on the existing road \\
Mining investors & No mining activity in the region \\
Hydropower establishers & No hydropower development in the region \\
Livestock raisers & Local people raised animals in very small numbers such as chickens and cows \\
\hline
\end{tabular}

\subsection{Appropriate REDD+ Activities to Address the Drivers of Deforestation and Forest Degradation}

Any introduction of REDD+ activities needs to be acceptable to the local residents, who will play multiple roles in implementing on-the-ground activities and monitor the performance of these REDD+ projects. Table 10 shows the levels of agreement between survey respondents regarding activities that may be introduced to address the drivers of D \& D. Out of the 18 types of activity inquired about, 11 were given an average score of above 4.0. Provision of sufficient farmland for family garnered the greatest agreement, followed by financial incentives for agriculture and law enforcement against illegal logging. On the other hand, livestock rangeland management received the lowest level of agreement as a measure for controlling D \& D. The top 11 types of activity are further explained in the following paragraphs. 
Table 10. Extent of agreement to the eighteen types of activities for addressing the drivers of deforestation and forest degradation in the study area $(n=215)$.

\begin{tabular}{|c|c|c|c|c|c|c|c|c|}
\hline \multirow{2}{*}{ Rank } & \multirow[t]{2}{*}{ Activity } & \multicolumn{5}{|c|}{$\begin{array}{l}\text { Frequency of Response (\% of Households) in Relation to Strongly } \\
\text { Disagree (1), Disagree (2), Neutral (3), Agree (4), Strongly Agree (5) }\end{array}$} & \multirow[t]{2}{*}{ Average Score (SD) } & \multirow{2}{*}{ Median Score } \\
\hline & & (1) & (2) & (3) & (4) & (5) & & \\
\hline 1 & Sufficient farmland for family & 0.0 & 0.0 & 9.3 & 31.2 & 59.5 & $4.50(0.66)$ & 5 \\
\hline 2 & Financial incentives for agriculture & 0.0 & 0.9 & 7.4 & 35.4 & 56.3 & $4.47(0.68)$ & 5 \\
\hline 3 & Law enforcement on illegal logging & 0.0 & 0.0 & 4.2 & 51.6 & 44.2 & $4.40(0.57)$ & 4 \\
\hline 4 & Improve market access for agricultural products & 0.0 & 2.3 & 2.3 & 54.4 & 40.9 & $4.34(0.64)$ & 4 \\
\hline 5 & Community forest management & 0.0 & 0.5 & 3.3 & 67.9 & 28.4 & $4.24(0.53)$ & 4 \\
\hline 6 & Policy and governance reform & 0.0 & 0.9 & 8.4 & 61.9 & 28.8 & $4.19(0.61)$ & 4 \\
\hline 7 & Reforestation/tree plantation & 0.0 & 1.9 & 9.8 & 60.9 & 27.4 & $4.14(0.66)$ & 4 \\
\hline 8 & Environmental education on forest management & 0.5 & 1.9 & 7.9 & 62.8 & 27.0 & $4.14(0.67)$ & 4 \\
\hline 9 & Land tenure and rights & 1.4 & 0.5 & 8.4 & 67.4 & 22.3 & $4.09(0.67)$ & 4 \\
\hline 10 & Agricultural intensification & 0.0 & 0.5 & 12.6 & 71.6 & 15.4 & $4.02(0.55)$ & 4 \\
\hline 11 & Restoration of degraded forests & 0.0 & 0.9 & 17.2 & 60.9 & 20.9 & $4.02(0.65)$ & 4 \\
\hline 12 & Good land use planning & 0.0 & 4.7 & 12.6 & 76.3 & 6.5 & $3.85(0.60)$ & 4 \\
\hline 13 & Environmental and social impact assessment for development proposal & 1.4 & 3.3 & 15.8 & 73.0 & 6.5 & $3.80(0.66)$ & 4 \\
\hline 14 & Fuelwood efficient cookstoves and rooftop solar power & 0.0 & 0.5 & 26.5 & 67.0 & 6.1 & $3.79(0.55)$ & 4 \\
\hline 15 & Build infrastructure for local employment & 1.4 & 5.1 & 22.8 & 62.3 & 8.4 & $3.71(0.75)$ & 4 \\
\hline 16 & Create alternative income opportunities & 1.9 & 7.9 & 23.7 & 60.0 & 6.5 & $3.61(0.80)$ & 4 \\
\hline 17 & Agroforestry & 1.4 & 4.2 & 34.9 & 51.6 & 7.9 & $3.60(0.75)$ & 4 \\
\hline 18 & Livestock rangeland management & 11.6 & 9.8 & 29.3 & 36.3 & 13.0 & $3.29(1.17)$ & 3 \\
\hline
\end{tabular}


Sufficient farmland for family: Respondents were in strong agreement $(90.7 \%)$ that their current farmland size was insufficient for supporting their growing family sizes. Average and median scores for this activity to reduce D \& D were high 4.50 (0.66 for standard deviation) and 5, respectively. In the rural areas, almost $100 \%$ of the Cambodian population depend almost entirely on agricultural cultivation $[81,82]$ to support their families. Since their farming activities can only be implemented in the rainy season (due to lack of rainfall in the dry season), more land is needed, unless water supplies are made available throughout the year. In the dry season, some farmers go to other provinces or cross the border into Thailand to look for work. The majority however, opt to look for timber and/or other forest products to sell, to support their family [83].

Financial incentives for agriculture: The average score for this activity was $4.47(0.68)$ and the median score was 5 . About $91.8 \%$ of respondents stated that this activity would reduce illegal logging by local residents because respondents had faced many problems in the past, such as prolonged drought during rainy seasons [84], uncertainty of harvesting yields due to natural hazards [85], variations in weather patterns [86], and fluctuations in crop price. The worst situations occurred at the start of the season, when they had to borrow money from others to begin agriculture, but poor harvests or low sale prices of agricultural products made it impossible for them to repay their debts to the lenders. This was also the reason that they had to find alternative sources of income by felling trees and selling cleared forest land. About $81 \%$ of respondents were farmers, and financial incentives for farming would encourage them to focus on working on their respective farms, rather than going into the forests to fell trees. In many parts of the tropics, financial incentives have reduced deforestation to some extent $[87,88]$.

Law enforcement on illegal logging: Average and median scores for this activity were $4.40(0.57)$ and 4, respectively. About $95.9 \%$ of respondents thought that for laws on logging to be respected and to reduce illegal logging, illegal loggers would have to be made to face maximum penalties. Based on the survey and focus group discussions, illegal logging and encroachment have been the main causes of forest loss in the region. It is usually difficult to stop illegal logging without interventions from the central government [89], especially if it is supported by powerful groups [89,90]. Many studies have found that law enforcement is critically required to reduce or eliminate illegal logging in the tropics [91-94]. Therefore, it is important to enforce logging laws and their associated regulations in order to reduce deforestation and forest degradation.

Improve market access for agricultural products: The average score was 4.33 . A total of $94.9 \%$ of respondents agreed that this activity would address forest degradation and deforestation. According to the focus group discussions, they believed that local residents were the main agents for almost every driver of deforestation and forest degradation. They argued that their activities were justified by the need to fulfill their daily needs and livelihood, because local farmers' crop calendars are dependent on rainfall and reaching the market. If there is more rain, farmers can increase crop production but their products cannot reach the market, forcing them to sell their products below the break-even price point before they go bad, as these farmers do not have the means to store their products any longer. As $81 \%$ of respondents are farmers, improving market access for their agricultural products is necessary to ease pressure on logging or clearing of forests. Recent studies indicate that improving marketing access for farmers can improve agricultural productivity $[95,96]$ and therefore, it can prevent locals from clearing forests in order to produce agricultural products to meet the needs of their families. The development of social enterprises for selling their products online or to ecotourism visitors could also connect their products to responsible consumers [97,98].

Community forest management: This activity refers to a coordinated effort to manage the forests, on which communities depend on for daily needs. The average score for this activity was 4.24 out of 5. About $95.4 \%$ of respondents were of the opinion that this activity is practical for addressing forest degradation and deforestation. Based on focus group discussions, participants strongly believed that community forest management could protect the remaining forests. They have witnessed the benefits of community forest management firsthand. They believed that only the community forests remained, 
as all the forested land outside the community forest had already been converted to agricultural land or cleared for other purposes. A meta-analysis of community forest management around the world found that community forest management is important for the long-term successful management of forests [99-101].

Policy and governance reform: The average score for this activity is 4.19. Respondents agreed that the government needs to reform its policies and governance toward natural resource use in favor of their expected activities in Table 11. Locals seemed to have lost their trust in the government because of corruption and on-going illegal logging in their areas, but policy and governance reform can lead to reductions in corruption among law enforcement officers at various levels. A previous study indicated that governance and policy reform could lead to reducing illegal logging and improving trust between locals and the government $[102,103]$.

Table 11. Proper activities to address deforestation and forest degradation in the study area according to the focus group discussions.

\begin{tabular}{|c|c|c|c|c|c|c|c|c|c|}
\hline \multirow[b]{2}{*}{ Activity } & \multicolumn{9}{|c|}{ Drivers } \\
\hline & 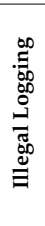 & 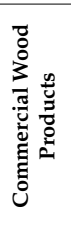 & 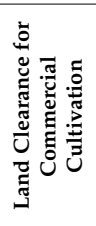 & 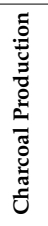 & 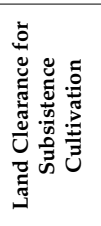 & 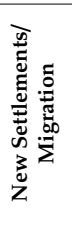 & 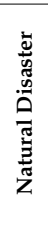 & 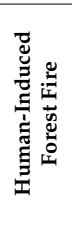 & 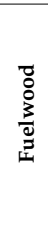 \\
\hline Sufficient farmland for family & & & & & $\sqrt{ }$ & & & & \\
\hline Financial incentives for agriculture & $\sqrt{ }$ & & & & & & & & \\
\hline Law enforcement against illegal logging & $\sqrt{ }$ & $\sqrt{ }$ & & $\sqrt{ }$ & & & & & \\
\hline Improved market access for agricultural products & $\sqrt{ }$ & & & & & & & & \\
\hline Community forest management & $\sqrt{ }$ & & & & & & & & \\
\hline Policy and governance reform & & & & & & & & & \\
\hline Reforestation/tree plantation & $\sqrt{ }$ & & & & & & $\sqrt{ }$ & $\sqrt{ }$ & $\sqrt{ }$ \\
\hline Environmental education on forest management & & $\sqrt{ }$ & & $\sqrt{ }$ & & & & $\sqrt{ }$ & $\sqrt{ }$ \\
\hline Land tenure and rights & & & & & $\sqrt{ }$ & $\sqrt{ }$ & & & \\
\hline Agricultural intensification & $\sqrt{ }$ & & & & $\sqrt{ }$ & & & & \\
\hline Restoration of degraded forests & $\sqrt{ }$ & & & & & & $\sqrt{ }$ & $\sqrt{ }$ & $\sqrt{ }$ \\
\hline
\end{tabular}

Reforestation and tree plantation: The average score for this activity was 4.14 . About $87.7 \%$ of respondents perceived that reforestation or tree plantations could address drivers of deforestation and forest degradation such as illegal logging, illegal encroachment, natural disasters, and the use of wood for commercial or domestic purposes. Reforestation is viewed as an important activity for increasing forest cover. Nurrochmat et al. [104] found that reforestation programs could reduce deforestation in Indonesia. A study in the Philippines shows similar results after reforestation projects were introduced [105].

Environmental education on forest management: The average score for this activity was 4.14. Of the respondents, $89.9 \%$ agreed on it as a solution for reducing the following drivers: forest fires, illegal logging, and land clearing without government permission. Education on sustainable use and harvesting of forest and non-forest products such as wild animals, wild fruits, wild vegetables, mushrooms, potatoes, honeys and bees, resin, bamboo shoot, rattan, herds, traditional medicines, and forest products can be an important avenue for reducing deforestation and forest degradation. Therefore, environmental education about how all necessary forest food and products can be obtained in a sustainable way is essential for local residents. For example, in order to get honey, locals use smoke to chase thousands of bees from their beehives. Forest fires can then be unintentionally started by careless bee hunters who do not keep their fires under control or left fires burning. Furthermore, the sustainable exploitation and use of wood can save many young and nearby trees. Therefore, environmental education on forest management can give local residents a broader picture of practical forest management and its long-term benefits, which can eventually reduce forest fires and forest clearing. A study of 101 local households in Honduras found that education could contribute to the reduction of deforestation [106]. 
Land tenure and rights: The average score for this activity was 4.09 . About $89.5 \%$ of respondents agreed that land tenure and rights could reduce land encroachment and land clearing drivers. Tenure is a term that describes rules regulating how people, communities, and others gain rights to land, water, fisheries, and forest, including access rights, management rights, and alienation rights. Local residents believe that land tenure can reduce illegal forest clearing and encroachment from the community. As there is no land tenure specified in the study area, residents tend to enlarge their land as much as possible. Moreover, without recognition of customary rights to their land, they have been afraid of losing their existing land, so they appear to use the land in an unsustainable way to extract the maximum benefits of land. Then, when their existing land loses fertility, they looked for new fertile land in forested areas. Tenure and rights are good measures to reduce deforestation and degradation caused by land tenure and rights issues and the problem of forest clearance for subsistent cultivation. The successful prevention of land encroachment and clearing due to this measure has been confirmed in previous studies [107-109].

Agricultural intensification: The average score for this activity was 4.02. Approximately $86.8 \%$ of respondents thought that agricultural intensification would reduce forest clearing for agriculture because it could increase productivity and income from existing cleared land as the same land can be further cultivated outside of the rainy season. Intensification of agriculture refers to a reduction in fallow, higher use of organic fertilizer to offset declines in soil fertility, and investments in mechanization and irrigation systems (thereby increasing the number of cycles of crop cultivation), which potentially offset the negative impact of population growth on farm size and can maintain or increase per capita food production [110]. Depending on location, building water tanks and/or the creation of water reservoirs to store water for year-round use can certainly increase crop production and improve the health of local residents. The use of IoT and big data technologies can also help manage water efficiently. However, a study by Phelps et al. [111] provided mixed results for agricultural intensification implemented at large scales because it can lead to increasing the conservation costs of the nearby forests. However, Pelletier et al. [112] indicated that reductions in deforestation based on agricultural intensification can only be achieved when smaller farms used higher quality seeds for farming.

Restoration of degraded forests: The score for this activity was 4.02. This activity refers to enrichment planting on degraded forest land in the community forests. About $81.7 \%$ of respondents agreed that restoration of degraded forests could solve the problem of forest degradation. This method is suitable for areas affected by overexploitation, natural disasters, and human-induced forest fires. It has been reported that restoration could avoid further deforestation and even increase carbon stocks in the tropics [113].

Table 11 illustrates which drivers of D \& D, with the potential to be addressed by certain activities, were assessed as promising. Many of the activities identified through our interviews and focus group discussions are expected to have the greatest reduction on reduce illegal logging practices, followed by human-induced forest fires and fuelwood collection.

On the contrary, the seven activities that did not receive a high level of agreement from the respondents are further summarized and discussed in Table 12, with closer attention to the foreseeable challenges and to implementations.

\subsection{Sociodemographic Factors Influencing Respondents' Perception}

Tables 13 and 14 show the results of the probit analysis of how sociodemographic factors influenced the perceived direct and indirect drivers of $\mathrm{D} \& \mathrm{D}$, perceived agents of $\mathrm{D} \& \mathrm{D}$, and perceived activities to address the drivers. To keep the tables succinct, only the summary of the sign and statistical significance of the estimated coefficients are displayed, while the full data tables are provided in the Supplementary Material.

Table 13 presents the results for the direct and indirect drivers. Four independent variables were found to have significant influences on many perceived drivers, namely: gender, income, CF membership, and participation in CF management. Agreement among women on direct and 
indirect drivers was generally lower than that among men. Seven out of the twenty drivers exhibited this gender gap. This implies that compared to the population, these drivers were underestimated in our sample, i.e., commercial wood production, land clearing for commercial agriculture, charcoal production, new settlements/migration limitation in law enforcement, population growth, and fertile land availability limitation. While income level showed a mixed result, low-income people perceived charcoal production and fuelwood collection to be a cause of forest resource degradation, presumably because they tended to consume more resources than their higher-income counterparts. With many of the drivers, community forest members had greater agreement than nonmembers, while participants in community forest management exhibited lower agreement than non-participants. Interestingly, this tendency was reversed for the indirect drivers that were considered the least important. This result implies that general members of community forests and those engaged in management showed contrasting perceptions of the drivers, where the perception by the former was largely consistent with the ranking of the drivers, while the perception by the latter group was relatively neutral across the drivers. The other sociodemographic factors showed smaller or had no impact on the drivers of D \& D in general.

In terms of perception of the groups responsible for $\mathrm{D} \& \mathrm{D}$, five independent variables showed significant influences on more than four perceived agents, i.e., gender, occupation, community forest membership, and participation in community forest management (Table 14). Men tended to agree more than women that these agents caused D \& D, especially agricultural investors. This implies that compared to population, five agents were underestimated in our sample, i.e., furniture makers, medium and large-scale agricultural investors, migrants, mining investors, and hydropower establishers. Farmers tended to mention shifting cultivators, subsistence farmers, and hydropower constructors, while non-farmers tended to cite investors in agriculture and migrants. However, those who were stably in the same job, farming or not, were more likely to think firewood collectors were responsible for D \& D. Similar to the case of the drivers, thoughts of general members of community forests tended to be in line with the ranking of the agents, whereas management members tended to have the opposite perceptions. The other sociodemographic factors showed either mixed, smaller, or no association with the perception of agents responsible for D \& D.

Table 12. Explanation of REDD+ activities not deemed by locals as appropriate for the study area.

\begin{tabular}{|c|c|c|}
\hline Activities & Characteristics & Application to Study Area and Challenges \\
\hline 1. Good land use planning & $\begin{array}{l}\text { Land use for sustainable use of the } \\
\text { natural resource }\end{array}$ & $\begin{array}{l}\text { Local people had less knowledge about the importance } \\
\text { of good land use planning. }\end{array}$ \\
\hline $\begin{array}{l}\text { 2. Environmental and social impact } \\
\text { assessment for development proposals }\end{array}$ & $\begin{array}{l}\text { The assessment on the impact of project } \\
\text { development on environment and society }\end{array}$ & $\begin{array}{l}\text { It is practiced in the region; however, economic } \\
\text { development variables are often the criteria to consider } \\
\text { to make the proposal accepted. }\end{array}$ \\
\hline $\begin{array}{l}\text { 3. Fuelwood-efficient cookstoves and } \\
\text { rooftop solar power }\end{array}$ & $\begin{array}{l}\text { Reduce the fuelwood demand for cooking } \\
\text { energy and other purposes }\end{array}$ & $\begin{array}{l}\text { Local people were not aware about the efficient } \\
\text { cookstoves as they still used the traditional 3-stone } \\
\text { cookstove. Solar is still unthinkable to the locals. }\end{array}$ \\
\hline $\begin{array}{l}\text { 4. Build infrastructure (schools, hospitals, } \\
\text { tourist centers) and employ local people }\end{array}$ & $\begin{array}{l}\text { Build schools, hospitals or tourist centers, then } \\
\text { hire local people to work }\end{array}$ & $\begin{array}{l}\text { Requires funds for development. } \\
\text { Need to have a solid plan and long-term investment. }\end{array}$ \\
\hline $\begin{array}{l}\text { 5. Create alternative income opportunities } \\
\text { such as eco-tourism, aquaculture, } \\
\text { handicrafts, and souvenirs }\end{array}$ & $\begin{array}{l}\text { - Promote ecotourism in the region } \\
\text { - Create income from aquaculture, handcrafts, } \\
\text { and souvenirs }\end{array}$ & $\begin{array}{l}\text { - Takes time to promote ecotourism and build the } \\
\text { reputation of ecotourism. } \\
\text { - Lack of staff with skills in tourism. } \\
\text { - Lack of support from local people in making } \\
\text { handicrafts (there used to be a handicraft store in Kbal } \\
\text { Doun Tey community where local people used to make } \\
\text { handicrafts, but it was not long until it closed). }\end{array}$ \\
\hline 6. Agroforestry & $\begin{array}{l}\text { - Trees or shrubs are grown around or on the } \\
\text { same land as agricultural crops and/or animals }\end{array}$ & - Not suitable in the study area. \\
\hline 7. Livestock/rangeland management & $\begin{array}{l}\text { - Management of the land for animal raising } \\
\text { especially the land that can provide forage }\end{array}$ & $\begin{array}{l}\text { - Not a problem for forest loss in the study area since } \\
\text { only less than } 1 \% \text { of respondents were livestock raisers. }\end{array}$ \\
\hline
\end{tabular}


Table 13. Sociodemographic factors influencing to the perceived direct and indirect drivers of 650 deforestation and forest degradation in the study area: probit regressions $(n=215)$.

\begin{tabular}{|c|c|c|c|c|c|c|c|c|c|c|c|c|}
\hline & & \multicolumn{11}{|c|}{ Sociodemographic Factors } \\
\hline & & 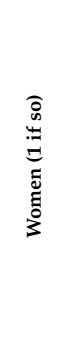 & 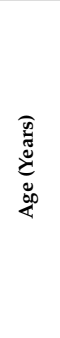 & 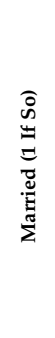 & 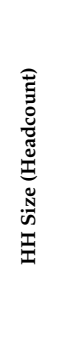 & 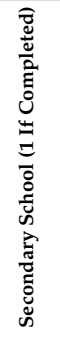 & 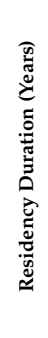 & 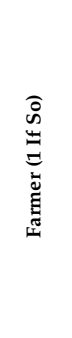 & 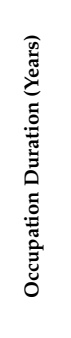 & 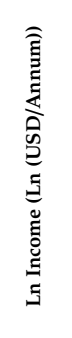 & 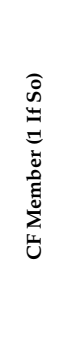 & 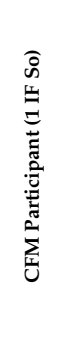 \\
\hline \multicolumn{13}{|c|}{ Direct drivers } \\
\hline 1 & Illegal logging/unauthorized forest encroachment & & & & ++ & & & & & & ++++ & --- \\
\hline 2 & Commercial wood production & --- & & & & & & & + & ++ & +++ & --- \\
\hline 3 & Land clearing for commercial agriculture & --- & & & & & & & & & +++ & --- \\
\hline 4 & Charcoal production & - & & & ++ & -- & & -- & & & & \\
\hline 5 & Land clearance for subsistence agriculture & & & & & & & & + & & & - \\
\hline 6 & New settlements/Migration & --- & -- & & & & & & & + & +++ & \\
\hline 7 & Natural disaster (flood, storm) & & & & & & + & & & & & \\
\hline 8 & Human-induced forest fire & & & & & & & & & + & + & --- \\
\hline 9 & Fuelwood (domestic usage or local consumption) & & & & & & + & + & & -- & & \\
\hline \multicolumn{13}{|c|}{ Indirect drivers } \\
\hline 1 & Limitation in law enforcement & --- & & & + & & & & & & +++ & --- \\
\hline 2 & Demand for timber & & & & + & & & & & +++ & +++ & -- \\
\hline 3 & Land tenure and rights issue & + & & & & & & & & ++ & & \\
\hline 4 & Population growth & --- & & & & & & -- & & & +++ & -- \\
\hline 5 & Fertile land availability limitation & --- & & + & & & & --- & & & +++ & -- \\
\hline 6 & Road construction & & & & & & & & & - & & \\
\hline 7 & Shifting cultivation & & ++ & -- & & & & +++ & --- & --- & --- & ++ \\
\hline 8 & Public service & & & & & & & & & --- & & \\
\hline 9 & Mining & & & & & & & -- & & +++ & --- & ++ \\
\hline 10 & Livestock grazing & & & & & & & & & & --- & +++ \\
\hline 11 & Hydropower development & & & & & & & & & + & --- & + \\
\hline
\end{tabular}

Note: + and - indicate a positive coefficient and a negative coefficient, respectively.,+++++ , and + indicate $p<0.01,<0.05$, and $<0.10$, respectively.

Table 14. Sociodemographic factors influencing the perceived agents responsible for deforestation and forest degradation in the study area: probit regression $(n=215)$.

\begin{tabular}{|c|c|c|c|c|c|c|c|c|c|c|c|c|}
\hline & & \multicolumn{11}{|c|}{ Sociodemographic Factors } \\
\hline & & 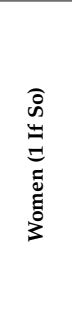 & 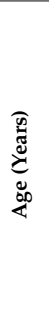 & 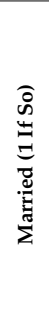 & 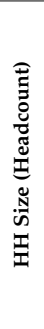 & 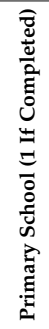 & 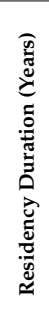 & 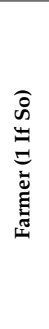 & 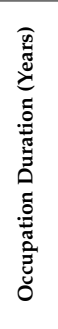 & 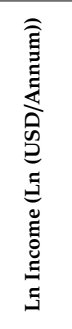 & 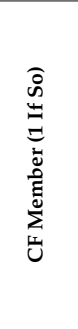 & 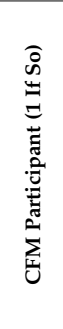 \\
\hline \multicolumn{13}{|c|}{ Agents } \\
\hline 1 & Furniture makers & -- & & -- & & & & & & +++ & +++ & --- \\
\hline $\begin{array}{l}2 \\
3\end{array}$ & $\begin{array}{l}\text { Medium and large-scale agricultural investors } \\
\text { Charcoal makers }\end{array}$ & --- & & & + & & & & + & & +++ & --- \\
\hline 4 & Migrants & - & - & & & & & - & & & +++ & --- \\
\hline 5 & Fire wood collectors & & & & & & -- & & ++ & & & - \\
\hline 6 & Subsistence farmers & & & & & & ++ & + & & & & \\
\hline 7 & Shifting cultivators & & & & & & & ++ & -- & --- & --- & +++ \\
\hline 8 & Infrastructural developers & & & & & & & & & --- & - & \\
\hline 9 & Mining investors & -- & & & & & & & & + & - & \\
\hline 10 & Hydropower establishers & - & & & & & & + & -- & & & \\
\hline 11 & Ranchers & & & & & & & & & & --- & +++ \\
\hline
\end{tabular}

Note: + and - indicate a positive coefficient and a negative coefficient, respectively.,+++++ , and + indicate $p<0.01,<0.05$, and $<0.10$, respectively.

Regarding which activities of REDD++ were conducive to reductions in D \& D in the study area, six independent variables were found to have significant influences on more than four perceived activities, i.e., gender, marriage, residency duration, income, community forest membership, and participation in community forest management (Table 15). The result on the gender effects implied that compared to population, the effectiveness of the following activities were underestimated in our 
sample, namely, having sufficient farmland for the family, law enforcement against illegal logging, and building infrastructure for local employment. Long-term residents tended to perceive these activities as conducive: securing enough farmland, controlling financial incentives for agriculture, conducting impact assessments, energy savings, and rangeland management. Income level was the factor most associated with the perception of activities for reducing D \& D, where wealthier people thought many of these activities to be effective; with the exceptions of policy reform and environmental education, which garnered more agreement by those of relatively lower socio-economic status. Community forest membership and participation in community forest management exhibited the same patterns as observed in the analysis of the drivers and agents. The other factors were relatively unrelated to the perception of effective activities.

Table 15. Sociodemographic factors influencing the perceived activities that can control deforestation and forest degradation in the study area: probit regression $(n=215)$.

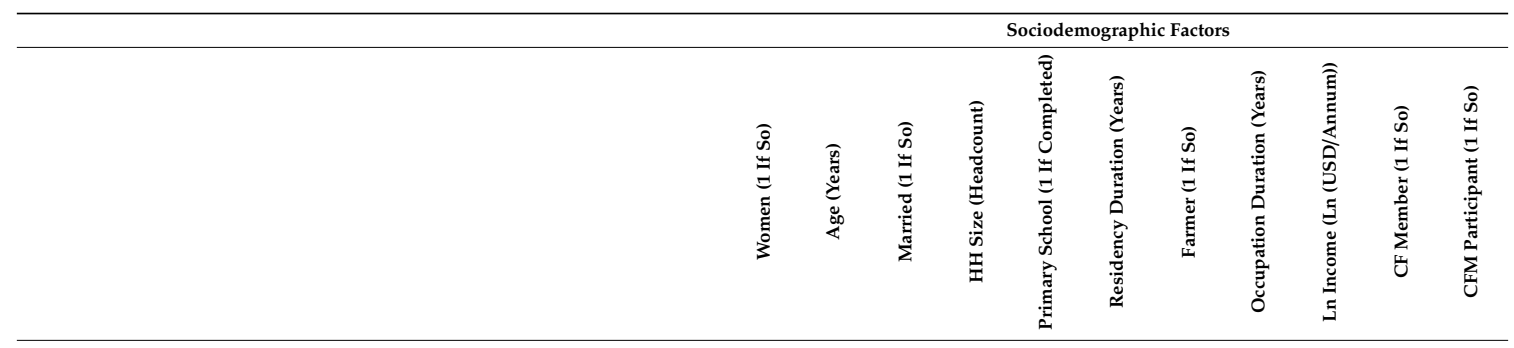

\begin{tabular}{|c|c|c|c|c|c|c|c|c|c|c|c|c|}
\hline \multicolumn{13}{|c|}{ Activities } \\
\hline 1 & Sufficient farmland for family & +++ & & - & & & ++ & & & & & \\
\hline 2 & Financial incentives for agriculture & & & & & & ++ & ++ & & ++ & & \\
\hline 3 & Law enforcement against illegal logging & --- & & & & & & & & +++ & +++ & --- \\
\hline 4 & Improved market access for agriculture products & & & ++ & & & & & + & & & \\
\hline 5 & Community forest management & - & & & & & & & ++ & & +++ & --- \\
\hline 6 & Policy and governance reform & & & ++ & ++ & & & & & -- & + & -- \\
\hline 7 & Reforestation/tree plantation & & & & ++ & & & +++ & & & & \\
\hline 8 & Environmental education on forest management & & & +++ & & & & & & --- & & \\
\hline 9 & Land tenure and rights & & - & & + & & & + & & & ++ & - - - \\
\hline 10 & Agricultural intensification & & & & & & & & & ++ & & \\
\hline 11 & Restoration of degraded forests & & & + & & & & + & + & +++ & & -- \\
\hline 12 & Good land use planning & +++ & & & & & & & & +++ & & \\
\hline 13 & Environmental and social impact assessment for development proposal & & -- & & & -- & ++ & & & +++ & - & + \\
\hline 14 & Fuelwood efficient cookstoves and rooftop solar power & & - - & & & - - & ++ & & & +++ & - & + \\
\hline 15 & Build infrastructure for local employment & ++ & & & & & & & & & --- & \\
\hline 16 & Create alternative income opportunities & & & & & & & & & & --- & +++ \\
\hline 17 & Agroforestry & & & & & & & & & & - - & \\
\hline 18 & Livestock rangeland management & & & & & + & + & & + & +++ & - - & \\
\hline
\end{tabular}

Note: + and - indicate a positive coefficient and a negative coefficient, respectively.,+++++ , and + indicate $p<0.01,<0.05$, and $<0.10$, respectively.

\section{Conclusions and Recommendations}

Data from 215 respondents in seven communities in Kampong Thom province, Cambodia were analyzed to understand the local perceptions of the direct and indirect drivers of deforestation and forest degradation, agents of such drivers, and appropriate activities to reduce these drivers according to five levels of the Likert scale. Local residents seem to accept that illegal logging and unauthorized forest encroachment (4.53), commercial wood production (4.20), and land clearing for commercial cultivation (large economic land concession) (4.19) were the main direct drivers of D \& D. Local people considered charcoal production (3.60), land clearing for subsistence agriculture (3.54), new settlements (3.43), natural disasters such as droughts and storms (3.31), human-induced forest fires (3.25), and fuelwood for domestic usage (3.21) as less relevant direct drivers. They considered the limitation in law enforcement (4.33), high demand for timber (4.15), lack of land tenure and rights (3.72), and the growing population (3.47) as indirect drivers of D \& D. Our results suggest that furniture makers, medium and large-scale agricultural investors, charcoal producers, land migrants, and local residents such as firewood collectors and subsistent famers were the agents of these drivers. Furthermore, local residents seemed to accept that these drivers can be reduced through the provision of farmland for households, financial incentives for agriculture, law enforcement on illegal logging, improvement in market access for agricultural products, community forest management, policy and 
governance reform, reforestation, environmental education on forest management, reform for land tenure and rights, agricultural intensification, and restoration of degraded forests.

Since these activities accepted by the local people are also REDD+ project activities, the REDD+ project can play an important role in the sustainable management of community forests, while providing carbon-based incentives and creating local development opportunities to ensure the long-term sustainability of projects and improve local livelihoods. As many potential REDD+ activities to reduce D \& D are still new to local residents, provision of training and environmental education may increase the success of reducing the drivers through the implementation of the REDD+ project. In designing the training and education programs, perception gap among different segments of people should be considered. For instance, as women tended to underestimate the importance of law enforcement against illegal logging and community forest management, gender sensitive sensitization $[114,115]$ in these topics may be useful. Likewise, community non-manager members were more likely to underestimate social impact assessment, fuelwood efficient cookstoves and rooftop solar power, building infrastructure for local employment, creation of alternative income opportunities, agroforestry, and livestock rangeland management. These subjects can be strengthened in interventions designed for community forest members.

Although the current study provides important information on local perceptions of direct and indirect drivers of $\mathrm{D} \& \mathrm{D}$, seasonal field surveys may further increase may reduce the biases that would result in a loss of memory about the exact events that occurred in the study area.

Supplementary Materials: The supplementary materials are available online at http://www.mdpi.com/2071-1050/ 12/23/9987/s1.

Author Contributions: Conceptualization, S.K., N.S.; methodology, S.K., N.S., T.E.; formal analysis, S.K., T.E., N.S., T.W.T.; investigation, S.K., P.T.; resources, H.O.M., N.S.,T.E., P.T.; data curation, S.K., N.S.; writing-original draft preparation, S.K., N.S.; writing-review and editing, N.S., T.E., T.W.T., H.O.M., P.T., S.K.; visualization, S.K., N.S.; supervision, T.E., N.S., T.W.T.; project administration, S.K., N.S.; funding acquisition, P.T., H.O.M., N.S. All authors have read and agreed to the published version of the manuscript.

Funding: This research was partially funded by the Forestry Administration under a joint FA-ITTO Project No. "PD 740/14 Rev. 2 (F): SFM through REDD+ Mechanisms in Kampong Thom Province, Cambodia".

Acknowledgments: The authors would like to thank Sokna Kry, a former student at the Natural Resources Management program at the Asian Institute of Technology in Thailand for assisting in data collection and drafting the related report. We also thank field staff of the Forestry Administration for assisting and facilitating the fieldwork.

Conflicts of Interest: The authors declare no conflict of interest.

\section{References}

1. Bahar, N.H.A.; Lo, M.; Sanjaya, M.; Van Vianen, J.; Alexander, P.; Ickowitz, A.; Sunderland, T. Meeting the food security challenge for nine billion people in 2050: What impact on forests? Glob. Environ. Chang. 2020, 62, 102056. [CrossRef]

2. Kolovos, K.G.; Kyriakopoulos, G.; Chalikias, M.S. Co-evaluation of basic woodfuel types used as alternative heating sources to existing energy network. J. Environ. Prot. Ecol. 2011, 12, 733-742.

3. Kyriakopoulos, G.L.; Kolovos, K.G.; Chalikias, M.S. Woodfuels prosperity towards a more sustainable energy production. In Proceedings of the Communications in Computer and Information Science, CCIS, Chennai, India, 23-25 July 2010; Springer: Berlin/Heidelberg, Germany, 2010; Volume 112, pp. 19-25.

4. Kyriakopoulos, G.L. European and international policy interventions of implementing the use of wood fuels in bioenergy sector: A trend analysis and a specific wood fuels' energy application. Int. J. Knowl. Learn. 2010, 6, 43-54. [CrossRef]

5. Filipa, A.; Id, P.; Santos-Filho, M.; Peres, C.A. Marked decline in forest-dependent small mammals following habitat loss and fragmentation in an Amazonian deforestation frontier. PLoS ONE 2020. [CrossRef]

6. Semper-pascual, A.; Decarre, J.; Baumann, M.; Busso, J.M.; Camino, M.; Gómez-valencia, B.; Kuemmerle, T. Biodiversity loss in deforestation frontiers: Linking occupancy modelling and physiological stress indicators to understand local extinctions. Biol. Conserv. 2019, 236, 281-288. [CrossRef] 
7. Giam, X. Global biodiversity loss from tropical deforestation. Proc. Natl. Acad. Sci. USA 2017, 114, 5775-5777. [CrossRef]

8. Gomes, V.H.F.; Vieira, I.C.G.; Salomão, R.P.; ter Steege, H. Amazonian tree species threatened by deforestation and climate change. Nat. Clim. Chang. 2019, 9, 547-553. [CrossRef]

9. Bebber, D.P.; Butt, N. Tropical protected areas reduced deforestation carbon emissions by one third from 2000 - 2012. Sci. Rep. 2017, 7, 1-7. [CrossRef]

10. Barlow, J.; Lennox, G.D.; Ferreira, J.; Berenguer, E.; Lees, A.C.; Mac Nally, R.; Thomson, J.R.; Ferraz, S.F.D.B.; Louzada, J.; Oliveira, V.H.F.; et al. Anthropogenic disturbance in tropical forests can double biodiversity loss from deforestation. Nature 2016, 535, 144-147. [CrossRef]

11. Houghton, R.A. Carbon emissions and the drivers of deforestation and forest degradation in the tropics. Curr. Opin. Environ. Sustain. 2012, 4, 597-603. [CrossRef]

12. NYDF Assessment Partners. Protecting and Restoring Forests A Story of Large Commitments. Available online: https://forestdeclaration.org/images/uploads/resource/2019NYDFReport.pdf (accessed on 29 October 2020).

13. Ty, S.; Sasaki, N.; Ahmad, A.H.; Ahmad, Z.A. REDD Development in Cambodia-REDD Project. Formath 2011, 10, 1-23. [CrossRef]

14. Ravikumar, A.; Sears, R.R.; Cronkleton, P.; Menton, M.; Pérez-Ojeda del Arco, M. Is small-scale agriculture really the main driver of deforestation in the Peruvian Amazon? Moving beyond the prevailing narrative. Conserv. Lett. 2017, 10, 170-177. [CrossRef]

15. Van Khuc, Q.; Tran, B.Q.; Meyfroidt, P.; Paschke, M.W. Drivers of deforestation and forest degradation in Vietnam: An exploratory analysis at the national level. For. Policy Econ. 2018, 90, 128-141. [CrossRef]

16. UNFCCC. Key Decisions Relevant for Reducing Emissions from Deforestation and Forest Degradation in Developing Countries (REDD+). Available online: https://unfccc.int/files/land_use_and_climate_change/ redd/application/pdf/compilation_redd_decision_booklet_v1.1.pdf (accessed on 29 November 2020).

17. Angelsen, A.; Arnesen, O.; Busch, J.; De Gregorio, M.; Hermansen, E.; Mcneill, D.; Ostwald, M.; Savedoff, W.; Seymour, F.; Al Vedeld, P.; et al. REDD+ as Result-based Aid: General Lessons and Bilateral Agreements of Norway. Rev. Dev. Econ. 2017, 21, 237-264. [CrossRef]

18. Curtis, P.G.; Slay, C.M.; Harris, N.L.; Tyukavina, A.; Hansen, M.C. Classifying drivers of global forest loss. Science 2018, 361, 1108-1111. [CrossRef]

19. Jayathilake, H.M.; Prescott, G.W.; Carrasco, L.R.; Rao, M.; Symes, W.S. Drivers of deforestation and degradation for 28 tropical conservation landscapes. Ambio 2020. [CrossRef] [PubMed]

20. Agarwal Green, G.; Grove, J.P.; Evans, T.; Schweik, C.; C Agrawal, A.; Nepstad, D.C.; Chhatre, A.; Ahmad, I.H.; Anderson, E.K.; Zerriffi, H.; et al. Drivers of Deforestation and Forest Degradation. Environ. Sci. Policy 2013, 4, 1-4. [CrossRef]

21. Salvini, G.; Herold, M.; De Sy, V.; Kissinger, G.; Brockhaus, M.; Skutsch, M. How countries link REDD+ interventions to drivers in their readiness plans: Implications for monitoring systems. Environ. Res. Lett. 2014, 9. [CrossRef]

22. Hosonuma, N.; Herold, M.; De Sy, V.; De Fries, R.S.; Brockhaus, M.; Verchot, L.; Angelsen, A.; Romijn, E. An assessment of deforestation and forest degradation drivers in developing countries. Environ. Res. Lett. 2012, 7. [CrossRef]

23. FCPF and UN-REDD. Readiness Preparation Proposal (R-PP) Assessment Note on the Proposed Project with SURINAME for REDD+ Readiness Preparation Support; World Bank (FCPF): Phnom Penh, Cambodia, 2011.

24. Skutsch, M.; Turnhout, E. Skutsch2020.pdf. World Dev. 2020, 130, 104942. [CrossRef]

25. Yamane, T. Statistics, an Introductory Analysis, 2nd ed.; Harper \& Row: New York, NY, USA, 1967.

26. Ban, N.C.; Picard, C.R.; Vincent, A.C.J. Comparing and integrating community-based and science-based approaches to prioritizing marine areas for protection. Conserv. Biol. 2009, 23, 899-910. [CrossRef] [PubMed]

27. Poudel, D.P. Migration, forest management and traditional institutions: Acceptance of and resistance to community forestry models in Nepal. Geoforum 2019, 106, 275-286. [CrossRef]

28. Engen, S.; Runge, C.; Brown, G.; Fauchald, P.; Nilsen, L.; Hausner, V. Assessing local acceptance of protected area management using public participation GIS (PPGIS). J. Nat. Conserv. 2018, 43, 27-34. [CrossRef]

29. Salaisook, P.; Faysse, N.; Tsusaka, T.W. Reasons for adoption of sustainable land management practices in a changing context: A mixed approach in Thailand. Land Use Policy 2020, 96, 104676. [CrossRef] 
30. Bhat, C.R.; Srinivasan, S. A multidimensional mixed ordered-response model for analyzing weekend activity participation. Transp. Res. Part B Methodol. 2005, 39, 255-278. [CrossRef]

31. Khai, T.C.; Mizoue, N.; Kajisa, T.; Ota, T.; Yoshida, S. Stand structure, composition and illegal logging in selectively logged production forests of Myanmar: Comparison of two compartments subject to different cutting frequency. Glob. Ecol. Conserv. 2016, 7, 132-140. [CrossRef]

32. Lynch, J.; Maslin, M.; Balzter, H.; Sweeting, M. Choose satellites to monitor deforestation. Nature 2013, 496, 293-294. [CrossRef]

33. Vidal, O.; López-García, J.; Rendón-Salinas, E. Trends in Deforestation and Forest Degradation after a Decade of Monitoring in the Monarch Butterfly Biosphere Reserve in Mexico. Conserv. Biol. 2014, 28, 177-186. [CrossRef]

34. Rudel, T.K.; Sloan, S.; Chazdon, R.; Grau, R. The drivers of tree cover expansion: Global, temperate, and tropical zone analyses. Land Use Policy 2016, 58, 502-513. [CrossRef]

35. Brancalion, P.H.S.; De Almeida, D.R.A.; Vidal, E.; Molin, P.G.; Sontag, V.E.; Souza, S.E.X.F.; Schulze, M.D. Fake legal logging in the brazilian amazon. Sci. Adv. 2018, 4, 1-8. [CrossRef]

36. Delux, C. Drivers of Deforestation in the Greater Mekong Subregion Cambodia Country Report. Available online: https://www.leafasia.org/sites/default/files/resources/Cambodia\%20Final-RevisedNov2015.pdf (accessed on 21 October 2020).

37. Bensel, T. Fuelwood, deforestation, and land degradation: 10 years of evidence from Cebu province, the Philippines. L. Degrad. Dev. 2008, 19, 587-605. [CrossRef]

38. Ali, J.; Benjaminsen, T.A. Fuelwood, timber and deforestation in the Himalayas: The case of Basho Valley, Baltistan Region, Pakistan. Mt. Res. Dev. 2004, 24, 312-318. [CrossRef]

39. Davis, K.F.; Yu, K.; Rulli, M.C.; Pichdara, L.; D'Odorico, P. Accelerated deforestation driven by large-scale land acquisitions in Cambodia. Nat. Geosci. 2015, 8, 772-775. [CrossRef]

40. Sedano, F.; Silva, J.A.; Machoco, R.; Meque, C.H.; Sitoe, A.; Ribeiro, N.; Anderson, K.; Ombe, Z.A.; Baule, S.H.; Tucker, C.J. The impact of charcoal production on forest degradation: A case study in Tete, Mozambique. Environ. Res. Lett. 2016, 11. [CrossRef]

41. Sonter, L.J.; Barrett, D.J.; Moran, C.J.; Soares-filho, B.S. Carbon emissions due to deforestation for the production of charcoal used in Brazil's steel industry. Nat. Clim. Chang. 2015, 5, 359-363. [CrossRef]

42. Chiteculo, V.; Lojka, B.; Surový, P.; Verner, V.; Panagiotidis, D.; Woitsch, J. Value chain of charcoal production and implications for forest degradation: Case study of Bié Province, Angola. Environments 2018, 5, 113. [CrossRef]

43. Forestry Administration. Cambodia Forestry Outlook Study; Asia-pacific forestry sector outlook study II: Working paper series. Working Paper No. APFSOS II/ WP/ 2010/ 32; FAO: Rome, Italy, 2010.

44. Henley, D. Swidden farming as an agent of environmental change: Ecological myth and historical reality in Indonesia. Environ. Hist. Camb. 2011, 17, 525-554. [CrossRef]

45. Styger, E.; Rakotondramasy, H.M.; Pfeffer, M.J.; Fernandes, E.C.M.; Bates, D.M. Influence of slash-and-burn farming practices on fallow succession and land degradation in the rainforest region of Madagascar. Agric. Ecosyst. Environ. 2007, 119, 257-269. [CrossRef]

46. Uitamo, E. Modelling deforestation caused by the expansion of subsistence farming in the Philippines. J. For. Econ. 1999, 5, 99-122.

47. Moonen, P.C.J.; Verbist, B.; Schaepherders, J.; Meyi, M.B.; Van Rompaey, A.; Muys, B. Actor-based identification of deforestation drivers paves the road to effective REDD+ in DR Congo. Land Use Policy 2016, 58, $123-132$. [CrossRef]

48. Milne, S. Grounding Forest Carbon: Property Relations and Avoided Deforestation in Cambodia. Hum. Ecol. 2012. [CrossRef]

49. Rudel, T.K.; Defries, R.; Asner, G.P.; Laurance, W.F. Changing drivers of deforestation and new opportunities for conservation. Conserv. Biol. 2009, 23, 1396-1405. [CrossRef] [PubMed]

50. Fearnside, P.M. Deforestation in Brazilian Amazonia: History, rates, and consequences. Conserv. Biol. 2005, 19, 680-688. [CrossRef]

51. Entwisle, B.; Rindfuss, R.R.; Walsh, S.J.; Page, P.H. Population growth and its spatial distribution as factors in the deforestation of Nang Rong, Thailand. Geoforum 2008, 39, 879-897. [CrossRef] [PubMed]

52. Binh, T.N.K.D.; Vromant, N.; Hung, N.T.; Hens, L.; Boon, E.K. Land cover changes between 1968 and 2003 in Cai Nuoc, Ca Mau Peninsula, Vietnam. Environ. Dev. Sustain. 2005, 7, 519-536. [CrossRef] 
53. Purnomo, H.; Shantiko, B.; Sitorus, S.; Gunawan, H.; Achdiawan, R.; Kartodihardjo, H.; Dewayani, A.A. Fire economy and actor network of forest and land fires in Indonesia. For. Policy Econ. 2017, 78, 21-31. [CrossRef]

54. Kim, S.; Sohn, H.G.; Kim, M.K.; Lee, H. Analysis of the Relationship among Flood Severity, Precipitation, and Deforestation in the Tonle Sap Lake Area, Cambodia Using Multi-Sensor Approach. KSCE J. Civ. Eng. 2019, 23, 1330-1340. [CrossRef]

55. Souza, C.M.; Siqueira, J.V.; Sales, M.H.; Fonseca, A.V.; Ribeiro, J.G.; Numata, I.; Cochrane, M.A.; Barber, C.P.; Roberts, D.A.; Barlow, J. Ten-year landsat classification of deforestation and forest degradation in the brazilian amazon. Remote Sens. 2013, 5, 5493-5513. [CrossRef]

56. Silva Junior, C.; Aragão, L.; Fonseca, M.; Almeida, C.; Vedovato, L.; Anderson, L. Deforestation-Induced Fragmentation Increases Forest Fire Occurrence in Central Brazilian Amazonia. Forests 2018, 9, 305. [CrossRef]

57. Adrianto, H.A.; Spracklen, D.V.; Arnold, S.R.; Sitanggang, I.S.; Syaufina, L. Forest and Land Fires Are Mainly Associated with Deforestation in Riau Province, Indonesia. Remote Sens. 2020, 12, 3. [CrossRef]

58. Alisjahbana \& Jonah, A.S.; Busch, M.M. Forestry, Forest Fires, and Climate Change in Indonesia. Bull. Indones. Econ. Stud. 2017, 53, 111-136. [CrossRef]

59. Deklerck, V.; De Mil, T.; Ilondea, B.A.; Nsenga, L.; De Caluwé, C.; Van den Bulcke, J.; Van Acker, J.; Beeckman, H.; Hubau, W. Rate of forest recovery after fire exclusion on anthropogenic savannas in the Democratic Republic of Congo. Biol. Conserv. 2019, 233, 118-130. [CrossRef]

60. Top, N.; Mizoue, N.; Kai, S. Estimating forest biomass increment based on permanent sample plots in relation to woodfuel consumption: A case study in Kampong Thom Province, Cambodia. J. For. Res. 2004, 9, 117-123. [CrossRef]

61. San, V.; Spoann, V.; Ly, D.; Chheng, N.V. Fuelwood consumption patterns in Chumriey Mountain, Kampong Chhnang Province, Cambodia. Energy 2012, 44, 335-346. [CrossRef]

62. Milne, S. Cambodia's Unofficial Regime of Extraction: Illicit Logging in the Shadow of Transnational Governance and Investment. Crit. Asian Stud. 2015, 47, 200-228. [CrossRef]

63. Santos de Lima, L.; Merry, F.; Soares-Filho, B.; Oliveira Rodrigues, H.; dos Santos Damaceno, C.; Bauch, M.A. Illegal logging as a disincentive to the establishment of a sustainable forest sector in the Amazon. PLoS ONE 2018, 13, 1-21. [CrossRef] [PubMed]

64. Degen, B.; Ward, S.E.; Lemes, M.R.; Navarro, C.; Cavers, S.; Sebbenn, A.M. Verifying the geographic origin of mahogany (Swietenia macrophylla King) with DNA-fingerprints. Forensic Sci. Int. Genet. 2013, 7, 55-62. [CrossRef]

65. Adams, M.A.; Kayira, J.; Tegegne, Y.T.; Gruber, J.S. A comparative analysis of the institutional capacity of FLEGT VPA in Cameroon, the Central African Republic, Ghana, Liberia, and the Republic of the Congo. For. Policy Econ. 2020, 112, 102108. [CrossRef]

66. Kishor, N.; Lescuyer, G. Controlling illegal logging in domestic and international markets by harnessing multi-level governance opportunities. Int. J. Commons 2012, 6, 255-270. [CrossRef]

67. Zhang, X.; Xu, B.; Wang, L.; Yang, A.; Yang, H. Eliminating illegal timber consumption or production: Which is the more economical means to reduce illegal logging? Forests 2016, 7, 191. [CrossRef]

68. Leipold, S.; Sotirov, M.; Frei, T.; Winkel, G. Protecting "First world" markets and "Third world" nature: The politics of illegal logging in Australia, the European Union and the United States. Glob. Environ. Chang. 2016, 39, 294-304. [CrossRef]

69. Anderson, C.M.; Asner, G.P.; Llactayo, W.; Lambin, E.F. Overlapping land allocations reduce deforestation in Peru. Land Use Policy 2018, 79, 174-178. [CrossRef]

70. Yanai, A.M.; de Alencastro Graça, P.M.L.; Escada, M.I.S.; Ziccardi, L.G.; Fearnside, P.M. Deforestation dynamics in Brazil's Amazonian settlements: Effects of land-tenure concentration. J. Environ. Manag. 2020, 268. [CrossRef] [PubMed]

71. Austin, K.G.; González-Roglich, M.; Schaffer-Smith, D.; Schwantes, A.M.; Swenson, J.J. Trends in size of tropical deforestation events signal increasing dominance of industrial-scale drivers. Environ. Res. Lett. 2017, 12, 054009. [CrossRef]

72. Meyfroidt, P.; Lambin, E.F. Forest transition in Vietnam and displacement of deforestation abroad. Proc. Natl. Acad. Sci. USA 2009, 106, 16139-16144. [CrossRef]

73. Grogan, K.; Pflugmacher, D.; Hostert, P.; Mertz, O.; Fensholt, R. Unravelling the link between global rubber price and tropical deforestation in Cambodia. Nat. Plants 2019, 5, 47-53. [CrossRef] 
74. Magliocca, N.R.; Khuc, V.; Ellicott, E.A.; De Bremond, A. Archetypical pathways of direct and indirect land-use change caused by Cambodia's economic land concessions. Ecol. Soc. 2019, 24. [CrossRef]

75. Chan, S.; Sasaki, N. Assessment of Drivers of Deforestation and Forest Degradation in Phnom Tbeng Forest Based on Socio-Economic Surveys. J. Environ. Prot. 2014. [CrossRef]

76. Kong, R.; Diepart, J.C.; Castella, J.C.; Lestrelin, G.; Tivet, F.; Belmain, E.; Bégué, A. Understanding the drivers of deforestation and agricultural transformations in the Northwestern uplands of Cambodia. Appl. Geogr. 2019, 102, 84-98. [CrossRef]

77. Miranda, J.; Börner, J.; Kalkuhl, M.; Soares-Filho, B. Land speculation and conservation policy leakage in Brazil. Environ. Res. Lett. 2019, 14. [CrossRef]

78. Perz, S.G.; Arambur'u, C.; Arambur'u, A.; Bremner, J. Population, land use and deforestation in the pan amazon basin: A comparison of brazil, bolivia, colombia, ecuador, per'uper' per'u and venezuela *. Dev. Sustain. 2005, 7, 23-49. [CrossRef]

79. Casse, T.; Milhøj, A.; Ranaivoson, S.; Randriamanarivo, J.R. Causes of deforestation in southwestern Madagascar: What do we know? For. Policy Econ. 2004, 6, 33-48. [CrossRef]

80. Kubitza, C.; Krishna, V.V.; Urban, K.; Alamsyah, Z.; Qaim, M. Land Property Rights, Agricultural Intensification, and Deforestation in Indonesia. Ecol. Econ. 2018, 147, 312-321. [CrossRef]

81. Dasgupta, S.; Deichmann, U.; Meisner, C.; Wheeler, D. Where is the poverty-environment nexus? Evidence from Cambodia, Lao PDR, and Vietnam. World Dev. 2005, 33, 617-638. [CrossRef]

82. Scheidel, A.; Farrell, K.N.; Ramos-Martin, J.; Giampietro, M.; Mayumi, K. Land poverty and emerging ruralities in Cambodia: Insights from Kampot province. Environ. Dev. Sustain. 2014, 16, 823-840. [CrossRef]

83. Beauchamp, E.; Clements, T.; Milner-Gulland, E.J. Exploring trade-offs between development and conservation outcomes in Northern Cambodia. Land Use Policy 2018, 71, 431-444. [CrossRef]

84. Chhinh, N. Drought, Drought Vulnerability and Adaptation Policy in Cambodia wiith Reference to the Farming Sector. PhD Thesis, Flinders University of South Australia, Adelaide, Australia, 2016.

85. Chantarat, S.; Oum, S.; Samphantharak, K.; Sann, V. Natural Disasters, Preferences, and Behaviors: Evidence from the 2011 Mega Flood in Cambodia. J. Asian Econ. 2019, 63, 44-74. [CrossRef]

86. Nguyen, T.T.; Nguyen, T.T.; Grote, U. Multiple shocks and households' choice of coping strategies in rural Cambodia. Ecol. Econ. 2020, 167, 106442. [CrossRef]

87. Brancalion, P.H.S.; Lamb, D.; Ceccon, E.; Boucher, D.; Herbohn, J.; Strassburg, B.; Edwards, D.P. Using markets to leverage investment in forest and landscape restoration in the tropics. For. Policy Econ. 2017, 85, 103-113. [CrossRef]

88. Newton, P.; Gomez, A.E.A.; Jung, S.; Kelly, T.; de Alencastro Mendes, T.; Rasmussen, L.V.; dos Reis, J.C.; Rodrigues, R.D.; Tipper, R.; van der Horst, D.; et al. Overcoming barriers to low carbon agriculture and forest restoration in Brazil: The Rural Sustentável project. World Dev. Perspect. 2016, 4, 5-7. [CrossRef]

89. Sunderlin, W.D. Poverty alleviation through community forestry in Cambodia, Laos, and Vietnam: An assessment of the potential. For. Policy Econ. 2006, 8, 386-396. [CrossRef]

90. Poffenberger, M. Cambodia' $s$ forests and climate change: Mitigating drivers of deforestation. Nat. Resour. Forum 2009, 33, 285-296. [CrossRef]

91. Mukul, S.A.; Herbohn, J.; Rashid, A.Z.M.M.; Uddin, M.B. Comparing the effectiveness of forest law enforcement and economic incentives to prevent illegal logging in. Int. For. Rev. 2020. [CrossRef]

92. Gavin, M.C.; Solomon, J.N.; Blank, S.G. Measuring and Monitoring Illegal Use of Natural Resources. Conserv. Biol. 2009, 24, 89-100. [CrossRef] [PubMed]

93. Van Der Ploeg, J.; Van Weerd, M.; Masipiqueña, A.B.; Gerard, A. Illegal Logging in the Northern Sierra Madre Natural Park, the Philippines. Conserv. Soc. 2011, 9, 202-215. [CrossRef]

94. Van Heeswijk, L.; Turnhout, E. Forest Policy and Economics The discursive structure of FLEGT ( Forest Law Enforcement, Governance and Trade): The negotiation and interpretation of legality in the EU and Indonesia. For. Policy Econ. 2013, 32, 6-13. [CrossRef]

95. Shiferaw, B.; Hellin, J.; Muricho, G. Improving market access and agricultural productivity growth in Africa: What role for producer organizations and collective action institutions? Food Secur. 2011, 475-489. [CrossRef]

96. Muhanji, G.; Roothaert, R.L.; Webo, C.; Stanley, M.; Muhanji, G.; Roothaert, R.L.; Webo, C.; Stanley, M.; Muhanji, G.; Roothaert, R.L.; et al. African indigenous vegetable enterprises and market access for small-scale farmers in East Africa African indigenous vegetable enterprises and market access for small-scale farmers in East Africa. Int. J. Agric. Sustain. 2011, 5903. [CrossRef] 
97. Kry, S.; Sasaki, N.; Datta, A.; Abe, I.; Ken, S.; Tsusaka, T.W. Assessment of the changing levels of livelihood assets in the Kampong Phluk community with implications for community-based ecotourism. Tour. Manag. Perspect. 2020, 34, 100664. [CrossRef]

98. Macqueen, D. Forest Connect: Reducing Poverty and Deforestation Through Support to Community Forest Enterprises. Int. For. Rev. 2016. [CrossRef]

99. Pagdee, A.; Kim, Y.; Daugherty, P.J.; Kim, Y. What Makes Community Forest Management Successful: A Meta-Study From Community Forests Throughout the World What Makes Community Forest Management Successful: A Meta-Study From Community Forests Throughout the World. Soc. Nat. Resour. 2007, 19, 33-52. [CrossRef]

100. Klooster, D.; Masera, O. Community forest management in Mexico: Carbon mitigation and biodiversity conservation through rural development. Glob. Environ. Chang. 2000, 10, 259-272. [CrossRef]

101. Bowler, D.E.; Buyung-ali, L.M.; Healey, J.R.; Jones, J.P.G.; Teri, M. Does Community Forest Management Provide Global Environmental Benefits and Improve Local Welfare? Front Does community forest management provide global environmental benefits and improve local welfare? Front. Ecol. Environ. 2012. [CrossRef]

102. Tacconi, L. National and International Policies to Control Illegal Forest Activities. Available online: https://www.semanticscholar.org/paper/National-and-International-Policies-to-Control-and-Tacconi/ 1da410d76153a26d7425708893772e7974ddd034 (accessed on 29 November 2020).

103. Larson, A.M.; Petkova, E. An Introduction to Forest Governance, People and REDD+ in Latin America: Obstacles and Opportunities. Forests 2011, 2, 86-111. [CrossRef]

104. Nurrochmat, D.R.; Massijaya, M.Y.; Jaya, I.N.S.; Abdulah, L.; Ekayani, M.; Astuti, E.W.; Erbaugh, J.T. Promoting community forestry to reduce deforestation surrounding Gunung Rinjani National Park in Central Lombok, Indonesia. IOP Conf. Ser. Earth Environ. Sci. 2019, 285. [CrossRef]

105. Dinh, H.; Smith, C.; Herbohn, J. What drives the success of reforestation projects in tropical developing countries? The case of the Philippines. Glob. Environ. Chang. 2014, 24, 334-348. [CrossRef]

106. Godoy, R.; Groff, S.; O'Neill, K. The Role of Ed ucation in Neotropical Deforestation: Househ old Evidence from Am erin dian s in Hon duras. Hum. Ecol. 1998, 26, 649-675. [CrossRef]

107. Wannasai, N.; Shrestha, R.P. Role of land tenure security and farm household characteristics on land use change in the Prasae Watershed, Thailand. Land Use Policy 2008, 25, 214-224. [CrossRef]

108. Corbera, E.; Estrada, M.; May, P.; Navarro, G.; Pacheco, P. Rights to Land, Forests and Carbon in REDD+: Insights from Mexico, Brazil and Costa Rica. Forests 2011, 2, 301-342. [CrossRef]

109. Robinson, B.E.; Holland, M.B.; Naughton-treves, L. Does secure land tenure save forests? A meta-analysis of the relationship between land tenure and tropical deforestation. Glob. Environ. Chang. 2014, 29, 281-293. [CrossRef]

110. Binswanger-Mkhize, H.P.; Savastano, S. Agricultural intensification: The status in six African countries. Food Policy 2017, 67, 26-40. [CrossRef] [PubMed]

111. Phelps, J.; Roman, L.; Webb, E.L.; Pin, L.; Pascual, U. Agricultural intensi fi cation escalates future conservation costs. PNAS 2013, 110. [CrossRef] [PubMed]

112. Pelletier, J.; Ngoma, H.; Mason, N.M.; Barrett, C.B. Does smallholder maize intensi fi cation reduce deforestation? Evidence from Zambia. Glob. Environ. Chang. 2020, 63, 102127. [CrossRef]

113. Edwards, D.P.; Fisher, B.; Boyd, E. Protecting degraded rainforests: Enhancement of forest carbon stocks under REDD +. Conserv. Lett. 2010, 3, 313-316. [CrossRef]

114. Basak, S. Empowering Women through Gender. North Asian Int. Res. J. Soc. Sci. Humanit. 2017, 3, 44-50.

115. Vasundhara, S. Importance of Gender Sensitization. Int. J. Multidiscip. Curr. 2020, 2, 120-125.

Publisher's Note: MDPI stays neutral with regard to jurisdictional claims in published maps and institutional affiliations. 